\title{
Meteotsunamis: atmospherically induced destructive ocean waves in the tsunami frequency band
}

\author{
S. Monserrat ${ }^{1,2}$, I. Vilibić $^{3}$, and A. B. Rabinovich ${ }^{4,5}$ \\ ${ }^{1}$ IMEDEA (UIB-CSIC), Palma de Mallorca, Spain \\ ${ }^{2}$ Departament de Física, Universitat de les Illes Balears, Palma de Mallorca, Spain \\ ${ }^{3}$ Institute of Oceanography and Fisheries, Split, Croatia \\ ${ }^{4}$ P. P. Shirshov Institute of Oceanology, Russian Academy of Sciences, Moscow, Russia \\ ${ }^{5}$ Institute of Ocean Sciences, Department of Fisheries and Oceans, Sidney BC, Canada
}

Received: 20 October 2006 - Accepted: 29 November 2006 - Published: 12 December 2006

\begin{abstract}
In light of the recent enhanced activity in the study of tsunami waves and their source mechanisms, we consider tsunami-like waves that are induced by atmospheric processes rather than by seismic sources. These waves are mainly associated with atmospheric gravity waves, pressure jumps, frontal passages, squalls and other types of atmospheric disturbances, which normally generate barotropic ocean waves in the open ocean and amplify them near the coast through specific resonance mechanisms (Proudman, Greenspan, shelf, harbour). The main purpose of the present study is to describe this hazardous phenomenon, to show similarities and differences between seismic and meteorological tsunamis and to provide an overview of meteorological tsunamis in the World Ocean. It is shown that tsunamis and meteotsunamis have the same periods, same spatial scales, similar physical properties and affect the coast in a comparably destructive way. Some specific features of meteotsunamis make them akin to landslide-generated tsunamis. The generation efficiency of both phenomena depend on the Froude number $(F r)$, with resonance taking place when $F r \sim 1.0$. Meteotsunamis are much less energetic than seismic tsunamis and that is why they are always local, while seismic tsunamis can have globally destructive effects. Destructive meteotsunamis are always the result of a combination of several resonant factors; the low probability of such a combination is the main reason why major meteotsunamis are infrequent and observed only at some specific locations in the ocean.
\end{abstract}

Correspondence to: I. Vilibić

(vilibic@izor.hr)

\section{Introduction}

"Tsunami" is a well known term commonly used (scientifically and colloquially) to refer to seismically generated ocean waves that have a typical period range from a few minutes to a few hours. As they approach the coast, these waves can produce severe damage to coastal structures and can cause the loss of human life. Nowadays, this term is mainly associated for earthquake generated events. However, the original meaning of the Japanese term "tsu-nami" is "a big wave in a harbour" without any reference to the source mechanism. The scientific community has generally accepted that "tsunami waves" may be also generated by some other mechanisms, specifically, by submarine landslides, volcanic eruptions or, asteroid/meteorite impacts. Although landslideor asteroid-generated tsunamis are clearly non-seismic, it is broadly admitted that sea level oscillations from these mechanisms should be also considered as tsunamis (Murty, 1977; Bryant, 2001).

There is, however, one more type of significant, even devastating, sea level oscillations at the coast with the same frequencies as typical tsunami waves. These oscillations are similar to ordinary tsunami waves (Fig. 1) and can affect coasts in a similar damaging way, although the catastrophic effects related to this type of waves are normally observed only in specific bays and inlets. These destructive waves are not related to any seismic activity, volcanic explosions, submarine landslides or meteorite impacts but to atmospheric forcing (atmospheric gravity waves, pressure jumps, frontal passages, squalls, etc.) (cf. Defant, 1961; Hibiya and Kajiura, 1982; Orlić, 1980; Rabinovich and Monserrat, 1996, 1998).

At certain places in the World Ocean, these hazardous sea level oscillations of meteorological origin are observed to occur regularly and have specific local names: "rissaga" in the

Published by Copernicus GmbH on behalf of the European Geosciences Union. 

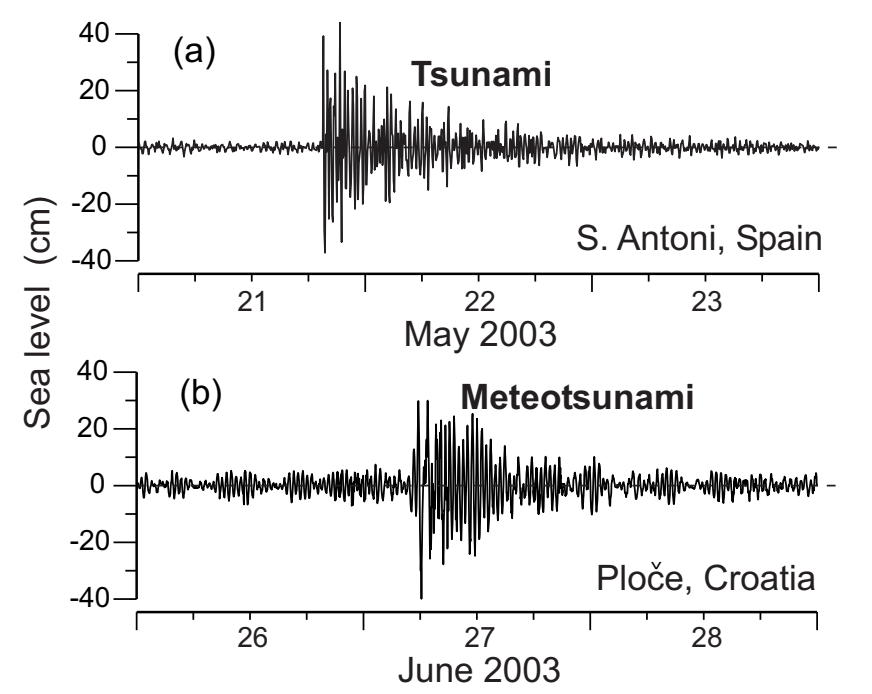

Fig. 1. (a) Tsunami oscillations recorded at Sant Antoni (Ibiza Island, Spain) after the Algerian earthquake of 21 May 2003; and (b) the meteotsunami recorded at Ploče Harbour (Croatia) on 27 June 2003. Both records have been high-pass filtered to eliminate oscillations with periods longer than $2 \mathrm{~h}$.

Balearic Islands (cf. Fontseré, 1934; Ramis and Jansà, 1983; Tintoré et al., 1988; Monserrat et al., 1991a); "marubbio" in Sicily (Colucci and Michelato, 1976; Candela et al., 1999); "milghuba" in Malta (Airy, 1878; Drago, 1999), "abiki" in Nagasaki Bay, Japan (Honda et al., 1908; Akamatsu, 1982; Hibiya and Kajiura, 1982), and "Seebär" in the Baltic Sea (Defant, 1961; Metzner et al., 2000). These waves are also documented in the Yellow Sea (Wang et al., 1987), the Adriatic Sea (Hodžić, 1979/1980; Orlić, 1980; Vilibić et al., 2004, 2005), the Aegean Sea (Papadopoulos, 1993), the English Channel (Douglas, 1929), the Great Lakes (Ewing et al., 1954; Donn and Ewing, 1956; Harris, 1957; Platzman, 1958, 1965; Donn, 1959; Irish, 1965), the northwestern Atlantic coast (Donn and McGuinness, 1960; Donn and Balachandran, 1969; Mercer et al., 2002), the Argentine coast (Dragani et al., 2002), and the New Zealand coast (Goring, 2003, 2005).

An example of such a strongly destructive event occurred recently (15 June 2006) in the region of the Balearic Islands (Western Mediterranean) when tsunami-like oscillations in Ciutadella Harbour (Menorca Island) damaged more than 40 boats and caused an economic loss of several tens millions of euros. These oscillations were not associated with any reported earthquake in the Mediterranean but were undoubtedly associated with an abrupt atmospheric pressure jump passing over the region (Monserrat et al., 2006).

Although different local events (like this destructive event in Ciutadella Harbour or the catastrophic event of 31 March 1979 in Nagasaki Bay described by Hibiya and Kajiura, 1982 and Akamatsu, 1982) have similar origins, there is no commonly recognized term to identify them. Several authors

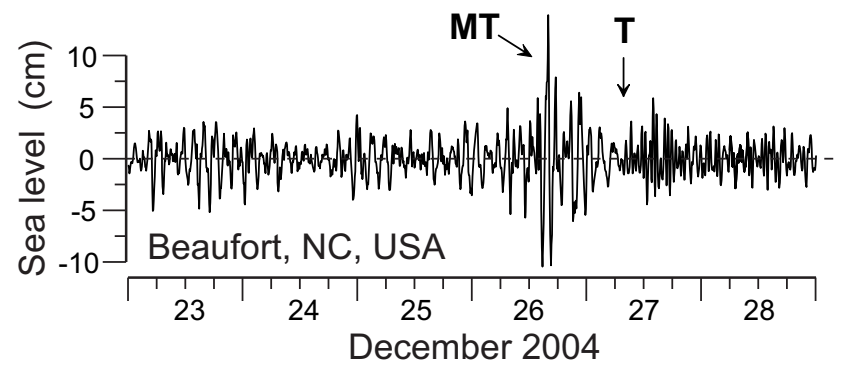

Fig. 2. Sea level oscillations at Beaufort (North Carolina, USA) for the period 23-28 December 2004. "MT" indicates intensive seiche oscillations generated by a strong storm travelling northward along the east coast of North America; "T" marks the arrival time of tsunami waves associated with the 2004 Sumatra earthquake (Rabinovich et al., 2006).

(cf. Nomitsu, 1935; Defant, 1961; Rabinovich and Monserrat, 1996, 1998; Bryant, 2001; González et al., 2001; Vilibić, 2005) suggest the term "meteotsunami" or "meteorological tsunami" (emphasizing their similarity to ordinary tsunami waves and following the use of the term "landslide tsunamis" for ocean waves generated by submarine slides and slumps). On the other hand, some controversy still remains on the proper use of this term within the tsunami scientific community. "Rissaga" (a local Catalan word that means 'drying", similar to the Spanish word "resaca") is probably the best known example of atmospherically induced destructive oscillations. For this reason, Derek Goring (New Zealand) suggested to use this term for similar phenomena in all areas of the World Ocean (cf. http://www.tideman. co.nz/DGGLWTimaru.htm and Goring, 2005). However, in that case, the strong relationship between "seismicallygenerated tsunamis", "landslide-generated tsunamis" and "meteotsunamis" may become lost and some confusion created.

Because of the strong similarity between atmospherically generated "meteotsunamis" and seismically generated tsunamis, it can be quite difficult to recognize one from another (Fig. 2). Catalogues of tsunamis normally contain many 'tsunami-like' events of "unknown origin" (Lander et al., 1993; Soloviev et al., 2000; Tinti et al., 2001, 2004) that, in fact, are atmospherically generated ocean waves.

The main goal of the present study is to describe this type of destructive wave, to demonstrate their strong similarity to ordinary tsunami waves, to indicate some differences and to provide an overview of them for the World Ocean. In Sect. 2, the essential characteristics of these waves are summarized. An attempt is made to define what kind of atmospherically induced waves should be considered as "meteotsunamis", in particular, how these waves should be distinguished from other types of sea level oscillations of meteorological origin such as storm surges or normal seiches that are commonly observed in bays, inlets and harbours. In Sect. 3, 
we discuss the similarities and differences between ordinary tsunamis and meteorological tsunamis, focussing on the generation, propagation, and inundation aspects of both phenomena. Some specific examples of meteotsunamis from various regions of the World Ocean are presented in Sect. 4. The main results are discussed and summarized in Sect. 5.

\section{Atmospherically generated long waves in the tsunami frequency band}

We can classify sea level oscillations at the coast through either their frequency content or their generation mechanism. Both are closely related because normally the source determines the frequency range of the generated oscillations. Wind waves have a clearly distinct frequency range than tides because the source mechanism acts at definitely different time and space scales. However, in many occasions, different sources may produce oscillations at the same frequencies (related, for example, to the eigen frequencies of the corresponding basin), while the same source may induce oscillations of different types and frequency ranges.

Atmospheric pressure is an example of a source affecting sea level over a very broad frequency range, from climatic variations to coastal seiches. Perhaps the best known type of pressure induced sea level variation is storm surges (Pugh, 1987). During passing cyclones, when atmospheric pressure decreases over a large ocean region, sea level increases due to the inverted barometer effect and, combined with wind forcing, may produce a significant inundation in coastal areas. On the other hand, high (anticyclonic) atmospheric pressure initiates a lowering of sea level and possible drainage of shallow-water areas. These large-scale sea level changes are hazardous, but they have nothing to do with tsunamis, mainly because of their quite different temporal and spatial scales, phase speed and general dynamics of the corresponding phenomena.

At the same time, atmospheric pressure changes can generate small-scale sea level oscillations with periods of a few minutes to a few hours. Normally, the energetic content of travelling atmospheric disturbances at these periods is relatively low and these oscillations form part of the background noise. On specific occasions, however, strong pressure disturbances may occur at these frequencies, e.g. trains of atmospheric gravity waves (Gossard and Munk, 1954; Monserrat et al., 1991a; Garcies et al., 1996) or isolated pressure jumps (Hibiya and Kajiura, 1982; Vilibić et al., 2004, 2005). These atmospheric disturbances may have different origin: dynamic instability, orographic influence, frontal passages, gales, squalls, storms, and tornados (Gossard and Hooke, 1975). Nevertheless, even during the strongest events, the atmospheric pressure oscillations at these scales typically reach only a few $\mathrm{hPa}$ (see examples in Fig. 3) that correspond only to a few $\mathrm{cm}$ of sea level change. Consequently, these atmospheric fluctuations can produce a significant sea level

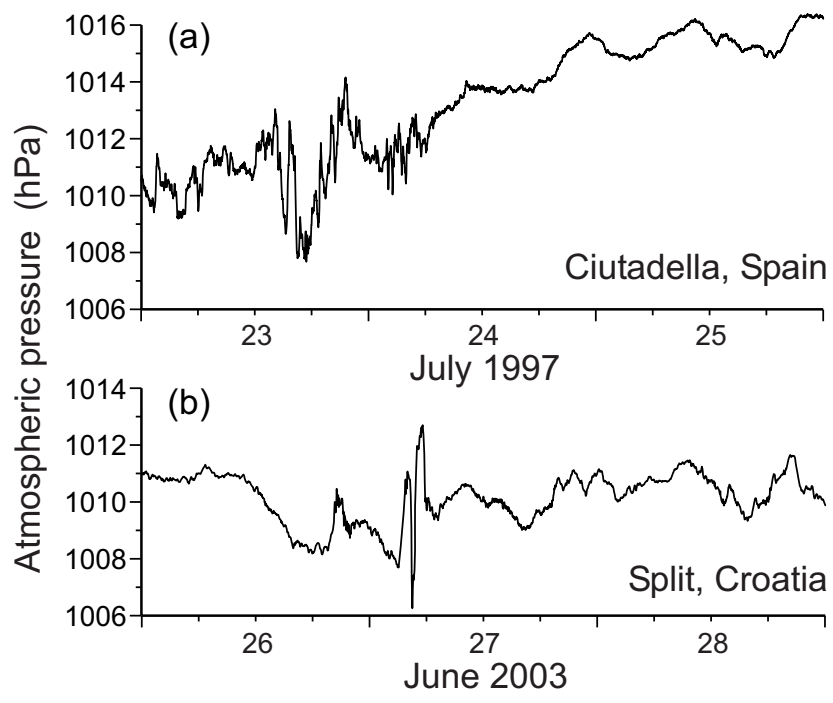

Fig. 3. High-resolution atmospheric pressure variations measured (a) at Ciutadella (Menorca Island, Spain) in July 1997, and (b) at Split (Croatia) in June 2003.

response only when some form of resonance occurs between the ocean and the atmospheric forcing. During resonance, the atmospheric disturbance propagating over the ocean surface is able to generate significant long ocean waves by continuously pumping energy into these waves.

Possible resonances are:

- "Proudman resonance" (Proudman, 1929), when $U=c$, i.e. the atmospheric disturbance translational speed $(U)$ equals the longwave phase speed $c=\sqrt{g h}$ of ocean waves;

- "Greenspan resonance" (Greenspan, 1956), when $U_{l}=c_{j}$, i.e. the alongshore component $\left(U_{l}\right)$ of the atmospheric disturbance velocity equals to the phase speed $c_{j}$ of the $j$-th mode of edge waves;

- "shelf resonance", when the atmospheric disturbance and associated atmospherically generated ocean wave have periods and/or wavelength equal to the resonant period and or wavelength of the shelf region.

There also some other types of resonance (cf. Rabinovich, 1993) but the above are likely the most important.

These resonant effects may significantly amplify ocean waves approaching the coast. Nevertheless, even strong resonant amplification of atmospherically generated ocean waves normally still cannot produce waves powerful enough to extensively affect the open coast (for example, a 3-4 hPa pressure jump and a 10-times resonant amplification will produce only $30-40 \mathrm{~cm}$ ocean waves). However, if these energetic ocean waves reach the entrance of a semi-closed coastal basin (bay, fjord or harbour) they may induce hazardous oscillations in the basin due to "harbour resonance" (Raichlen, 1966; Mei, 1992). 
Harbour oscillations are not generated locally by a direct forcing inside the basin but are induced by ocean waves arriving from the open sea (cf. Wilson, 1972; Miles, 1974). Intensive oscillations inside a harbour (bay or inlet) may be formed only if the external forcing (the arriving opensea waves) are high enough. Seismically generated tsunami waves in the open ocean can be sufficiently strong even without any additional resonant effects (for example, satellite altimetry measurements show that tsunami waves generated by the 2004 Sumatra earthquake in the open part of the Indian Ocean had trough-to-crest wave heights of approximately 1.0-1.2 m; cf. Fine et al., 2005), while atmospherically generated tsunami-like waves can attain potentially dangerous levels only if there is some local or regional topographic resonance. This is an important difference between tsunami waves and meteotsunamis.

The presence of energetic external waves is a necessary but not a sufficient condition for the formation of strong atmospherically generated seiches in harbours. Strong harbour oscillations may be produced only if the corresponding inner basin has well-defined resonant properties and a large $Q$ factor (Raichlen, 1966). The amplification factor for long waves arriving at a harbour from the open sea may be approximated as

$$
H^{2}(f)=\frac{1}{\left(1-f / f_{0}\right)^{2}+Q^{-2}\left(f / f_{0}\right)^{2}},
$$

where $f$ is the frequency of the long waves, $f_{0}$ is the resonant frequency of the harbour, and $Q$ is the quality factor, which is a linear measure of the energy damping in the system (Miles and Munk, 1961; Raichlen, 1966). At resonance, $f=f_{0}$, and the power amplification factor attains the value $Q^{2}$. The factor decreases to unity for $f=0$ and goes to zero as $f$ goes to infinity. Therefore, $Q$ for harbour oscillations plays a double role: it is a measure of the resonant increase of wave heights for the waves arriving from the open ocean and also acts as an index of the time decay rate of wave heights inside the harbour. Narrowing the harbour entrance increases the quality factor $Q$ and, consequently, the amplification of the arriving waves. That is why significant seiches are normally observed only in elongated and narrow inlets (fjords) or for bays (harbours) with narrow entrances. The well known "harbour paradox" of Miles and Munk (1961) discusses why it is that the narrower the entrance to the harbour and the better the harbour is protected from incoming wind waves and swell, the stronger the seiche oscillations inside the harbour.

As indicated by expression (1), a large $Q$-factor is crucial but that intense harbour oscillations can be produced only for the resonant case of matching between the dominant frequency $(f)$ of the arriving (external) waves and an eigenfrequency $f_{0}$ of the harbour (normally, the eigenfrequency of the fundamental or Helmholtz harbour mode). This means that catastrophic harbour oscillations are the result of a "double resonance effect" (Rabinovich, 1993): (a) "external resonance" between the moving atmospheric disturbance and the open-ocean waves; and (b) "internal resonance" between the arriving open-ocean waves and the fundamental eigenmode of the harbour (bay, inlet). An additional favourable factor is the specific direction of propagating atmospheric waves (and corresponding open-ocean waves) toward the entrance of the embayment.

We can sumarize the particular conditions needed for the generation of extreme atmospherically induced oscillations near the coast (meteotsunamis):

- A harbour (bay, inlet or gulf) with definite resonant properties and high $Q$-factor.

- Strong small-scale atmospheric disturbance (a pressure jump or a train of internal atmospheric waves).

- Propagation of the atmospheric disturbance toward the entrance to the harbour.

- External resonance (Proudman, Greenspan or shelf resonance) between the atmospheric disturbance and ocean waves.

- Internal resonance between the dominant frequency of the arriving open-ocean waves and the fundamental harbour mode frequency.

Due to the necessary of matching between the atmospheric disturbance, the open ocean bathymetry and the shelfharbour geometry, the direction and speed of the atmospheric disturbance probably are even more important than the actual energy content. In any case, the needed coincidence of several factors significantly diminishes the possibility of observing these events, which is the main reason why these phenomena are rare and restricted to specific locations (Rabinovich, 1993).

Honda et al. (1908) and later Nakano and Unoki (1962) investigated more than one hundred gulfs, bays, inlets, and harbours along the Japanese coast and found that large seiches (not associated with tsunami waves) occur only in a few of them. Significant sea-level oscillations and currents are mainly recorded in elongated, shallow and narrow-mouthed inlets or bays, in good agreement with the Miles and Munk (1961) theory. Extremely strong seiche oscillations ("abiki" waves) are periodically excited in Nagasaki Bay. In particular, the "abiki" waves of 31 March 1979 with a period of about $35 \mathrm{~min}$ reached a wave height of $478 \mathrm{~cm}$ at the northern end of the bay and killed three people (Akamatsu, 1982; Hibiya and Kajiura, $1982=$ HK in the following text).

The high meteotsunami risk for some exceptional locations is mainly related to a combination of shelf topography and coastline geometry, creating together the double resonance effect. Two factors (internal and external) are critical: (1) well-defined resonant characteristics of the harbour (bay, or inlet); and (2) specific properties of the shelf which are favourable for the external resonance between atmospheric 


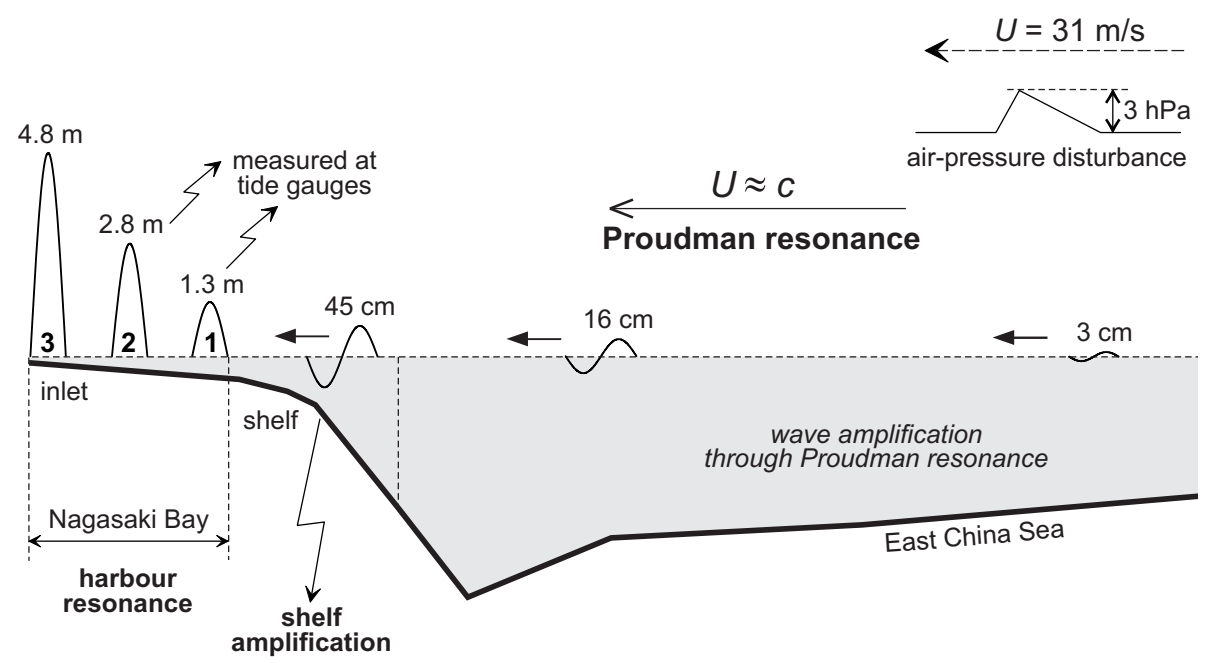

Fig. 4. A sketch illustrating the physical mechanism responsible for formation of the catastrophic meteotsunami at Nagasaki Bay (Japan) on 31 March 1979. The initial pressure jump over the western part of the East China Sea was about $3 \mathrm{hPa}$. The long waves generated by this event first amplified from $3 \mathrm{~cm}$ to $16 \mathrm{~cm}$ as a result of the Proudman resonant effect, then to $45 \mathrm{~cm}$ due to the shelf amplification and finally to $478 \mathrm{~cm}$ at the head of the bay due to the harbour resonance. Numbers " 1 ", " 2 ", and " 3 " correspond to locations shown in the inset in Fig. 5a.
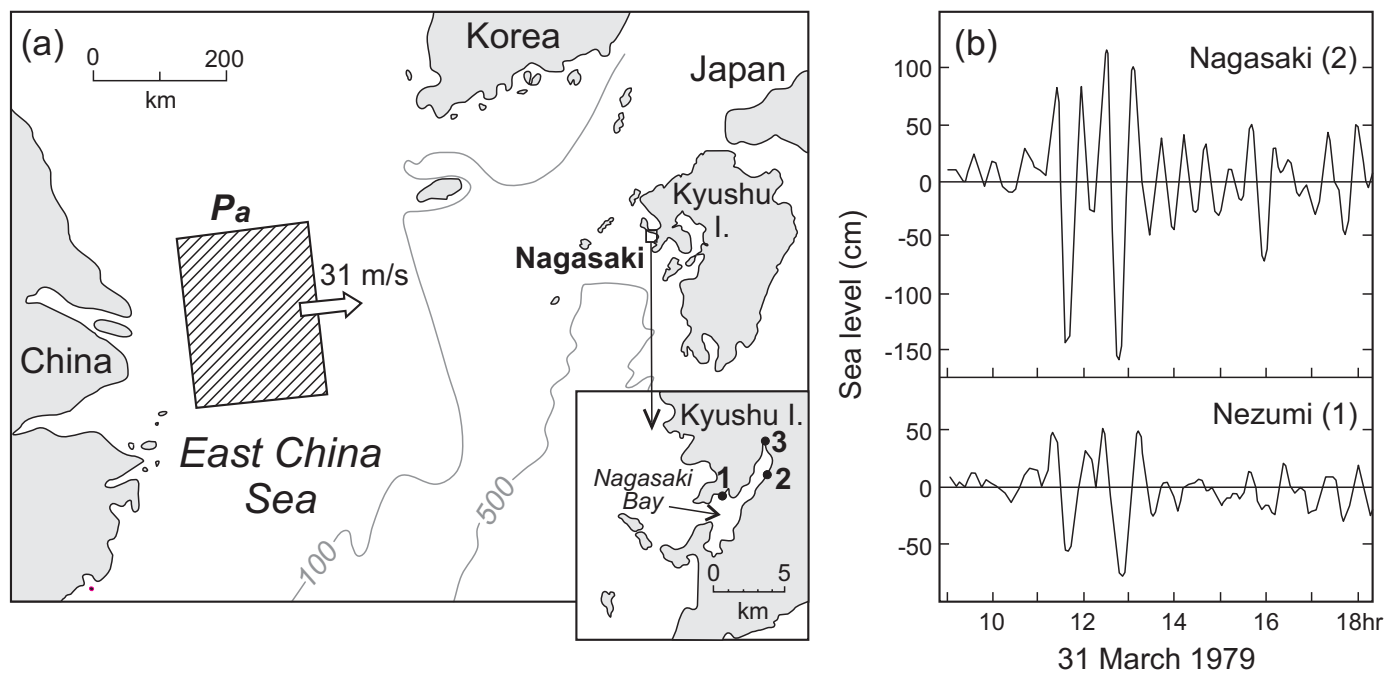

Fig. 5. (a) A map showing the location of Nagasaki Bay and the site of the initial atmospheric pressure disturbance (shaded rectangular); numbers " 1 " and " 2 " in the inset indicate positions of tide gauges Nezumi and Nagasaki, respectively; site " 3 " is at the head of the bay where the maximum wave of $478 \mathrm{~cm}$ was observed on 31 March 1979. (b) Tide gauge records of the catastrophic meteotsunami ("abiki waves") of 31 March 1978 at Nezumi (1) and Nagasaki (2); positions of the tide gauges are shown in the inset in panel (a).

and open-ocean waves and the internal resonance between arriving open-ocean waves and harbour oscillations. The combination of these two factors for some particular sites is like a "ticking time-bomb": sooner or later - when the atmospheric disturbance is intense enough and the parameters of the disturbance coincide with the resonant parameters of the corresponding shelf topography and embayment geometry - it will "explode". Those particular oceanic locations that experience frequent extreme seiches are representative of such "ticking time-bomb" sites.
The catastrophic event of "abiki" waves of 31 March 1979 may be used as an example to illustrate the physical mechanism responsible for the generation of meteotsunamis (Fig. 4). HK examined this event in detail and constructed an efficient numerical model that agrees well with the observational data. Nagasaki Bay is a narrow, elongated bay located on the western coast of Kyushu Island, Japan (Fig. 5); the length of the bay is about $6 \mathrm{~km}$, the width is $1 \mathrm{~km}$ and the mean depth is $20 \mathrm{~m}$. The fundamental period of the bay (Helmholtz mode) is $35 \mathrm{~min}$; this period strongly prevails in seiche oscillations inside the bay (95\% of all observed 
events) and this period was observed on 31 March 1979 (Akamatsu, 1982). HK noticed that almost all known cases of significant "abiki" waves are associated with pressure jumps; for the latter case, an abrupt pressure jump $\left(\Delta P_{a}\right)$ of 2 to $6 \mathrm{hPa}$ (according to observations at several sites) propagated eastward (more precisely, $5.6^{\circ}$ north of east) over the East China Sea with a mean speed $U$ of about $31 \mathrm{~m} / \mathrm{s}$ (Fig. 5). The authors (HK) approximated this jump as having a peak value of $\Delta P_{a}=3 \mathrm{hPa}$ with a leading linear increase over a scale $L_{1}=28 \mathrm{~km}$ and a tailing linear decrease over a scale $L_{2}=169 \mathrm{~km}$. The corresponding static inverted barometer response was $\Delta \bar{\zeta} \approx-3 \mathrm{~cm}$ (Fig. 4). Since the depth of the East China Sea between mainland China and Kyushu Island is between 50 and $150 \mathrm{~m}$, the longwave speed $c \approx 22-39 \mathrm{~m} / \mathrm{s}$. Thus, this event was a classical example of Proudman resonance. HK presented a simple expression for the resonantly amplified open-ocean long waves as

$\Delta \zeta=\frac{\Delta \bar{\zeta}}{L_{1}} \frac{x_{f}}{2}$,

where $x_{f}=U t$ is the distance travelled by the pressure jump during time $t$. Using $L_{1}=28 \mathrm{~km}$ and $x_{f}=300 \mathrm{~km}$ (the distance from the source area to the Goto Islands - see Fig. 5), then $\Delta \zeta \approx 16 \mathrm{~cm}$. More precise numerical computations using realistic two-dimensional seafloor topography gives the resonant factor as $\varepsilon=\Delta \zeta / \Delta \bar{\zeta}=4.3$ and $\Delta \zeta \approx 12.9 \mathrm{~cm}$, in good agreement with observations. So, due to resonance, the initial disturbance of $3 \mathrm{~cm}$ increased in the open sea by 4-5 times (Fig. 4). It is interesting from Eq. (2) that the resonant amplification is inversely proportional to $L_{1}$, whereby the faster the change in atmospheric pressure (i.e. the more abrupt is the pressure jump), the stronger is the amplification of the generated waves (HK).

According to the computations of HK, the outer shelf region between the Goto Islands and the mainland of Kyushu ("Goto Nada") has resonant periods of 64, 36 and $24 \mathrm{~min}$. The period of $36 \mathrm{~min}$ closely coincides with the fundamental period (35 min) of Nagasaki Bay. The Goto Nada shelf did not significantly amplify the leading incoming wave (first crest height was $16 \mathrm{~cm}$ at the shelf entrance) but selected and amplified waves with the specific period of $36 \mathrm{~min}$. Between the outer shelf (depth $60 \mathrm{~m}$ ) and the head of Nagasaki Bay, the arriving waves were amplified by a factor of 2.4 due to the combined effects of topographic funnelling, partial reflection, and shoaling inside the bay. Finally, the resonant amplification in Nagasaki of the incoming wave train with a period of about $35 \mathrm{~min}$ forms catastrophic oscillations within the bay with a maximum recorded wave height of $134 \mathrm{~cm}$ at Nezumi (\#1) located near the bay entrance (see Fig. 5a for the tide gauge position and Fig. $5 \mathrm{~b}$ for the record). A $278 \mathrm{~cm}$ wave height was recorded at Nagasaki (\#2) as measured by a tide gauge located in the middle of the bay (Figs. 5a and b). The estimated wave height for the head of the bay (\#3) was $478 \mathrm{~cm}$ (Akamatsu, 1982). Thus, for this extreme event we see the entire combination of "hazardous" amplification factors responsible for formation of catastrophic oscillations inside Nagasaki Bay: (1) a strong atmospheric disturbance (pressure jump of 2 to $6 \mathrm{hPa}$ ) propagating (2) toward the bay with (3) near-resonant phase speed of $31 \mathrm{~m} / \mathrm{s}$. This disturbance resonantly generated open-sea long waves over the shelf with a selected $36 \mathrm{~min}$ period matching (4) the fundamental 35-min period of the bay that has (5) a high $Q$-factor and well-defined resonant properties. As a result, $3 \mathrm{~cm}$ ocean waves in the source area give rise to $478 \mathrm{~cm}$ waves at the head of the bay (Fig. 4).

Analysis of destructive meteotsunami events in the Mediterranean (Orlić, 1980; Gomis et al., 1993; Rabinovich and Monserrat, 1996, 1998; Monserrat et al., 1998; Vilibić et al., 2004, 2005; Vilibić, 2005) indicated that the physical mechanisms of these events were similar to the considered event in Nagasaki Bay. Tides in the Mediterranean are small; consequently, the harbour structures are not prepared to accommodate large amplitude sea level changes associated with occasional meteotsunamis. However, it is the latter (not ordinary tsunamis or storm surges) that are normally responsible for significant floods and damage in this region. It is likely that much of the damage from meteotsunamis is related to the strong currents in the harbour accompanying the sea level oscillations. Seiches with a $10 \mathrm{~min}$ period give raise to currents 70 times stronger than semidiurnal tides having the same amplitude.

The principal question is: What should be considered as a meteotsunami event? In order to determine a "meteotsunami" event, we should specify some criteria. From this point of view, the situation is quite different from that for ordinary tsunamis: all seismically-generated water waves are considered "tsunamis" independently of whether they have a wave height of a few millimetres or several tens of metres. However, this approach cannot be adopted for meteotsunamis. Examining sea level variations in a harbour, we must take into account that the atmosphere is the main source of energy of these variations. For the tsunami frequency range (for periods of $2 \mathrm{~min}$ to $2 \mathrm{~h}$ ) about $99 \%$ of the energy of background oscillations is related to the meteorological forcing (wind and atmospheric pressure). So it is pointless to specify all these oscillations as meteotsunamis. Rabinovich and Monserrat (1996) selected as "rissagas" all seiche events in Ciutadella Inlet (Balearic Islands) with sea level changes exceeding $30 \mathrm{~cm}$. However, this threshold may vary from one site to another due to the different levels of background noise. A possible compromise is to use as a threshold, wave amplitude exceeding three or four sigma (rms) or to use both criteria (absolute and relative wave heights). An alternative approach is to consider as "meteotsunamis" only potentially damaging events; this approach is much more restrictive and for practical point of view has some advantages because it filters out numerous minor events. However as a scientific criterion, we suggest use of a combined threshold criterion based on four-sigma value and absolute wave that may be specified for any given region. 


\section{Similarities and differences between ordinary tsunamis and meteotsunamis}

The principal similarities and differences between meteotsunamis and seismically generated tsunamis can be discussed for the three stages of the tsunami process: generation, propagation and inundation/harbour resonance. Both tsunamis and meteotsunamis are determined by two major factors: (1) source, and (2) topography (cf. Rabinovich, 1997; Monserrat et al., 1998; Rabinovich and Stephenson, 2004). Topography for both phenomena is the same, but their sources are different. Consequently, we may assume that the similarities in these two phenomena are mainly due to topography, which affects tsunamis and meteotsunamis in a similar way, while the differences are associated with specific properties of the corresponding sources.

\subsection{Generation}

This stage is the most different for the two processes. The different sources of meteotsunamis and seismic tsunamis have consequences for the recorded waves, being responsible for the observed wave peculiarities. The most important dissimilarity is that meteotsunamis never attain the high energy values of major seismic tsunamis. This yields two important corollaries:

1. A major seismic tsunami is a transoceanic (sometimes even global) event that can have a destructive effect on coasts located many thousands of kilometres from the source area (as was observed for the catastrophic Sumatra tsunami of 26 December 2004 in the Indian Ocean, see Titov et al., 2005; Rabinovich et al., 2006). In contrast, meteotsunamis are always local; damaging oscillations are normally observed only in a specific bay (harbour) or in a few neighbouring bays. From this point of view, meteotsunamis are similar to landslidegenerated tsunamis that also commonly have only a local effect.

2. As was mentioned above, a tsunami generated by a major earthquake can be sufficiently energetic to cause severe damage on the coast without additional resonant effects, while a meteotsunami can achieve this level only in the case of multiple resonance.

A second important dissimilarity is related to the generation mechanism. A submarine earthquake may be considered as an impulse tsunami source. Consequently, tsunami waves generated by an earthquake may be treated as a classical Cauchy-Poisson problem for which the initial surface elevation is the same as the displacement of the bottom thereby converting the problem into an initial value problem of wave propagation (cf. Jiang and LeBlond, 1992). In contrast, an atmospheric disturbance has considerable duration; propagated surface waves interact with the disturbance which generated them, and this interaction (in fact, continuous energy pumping) is the crucial factor in resonant amplification of atmospherically induced ocean waves.

The entire problem of meteotsunami generation is very similar to the problem of the tsunami generation by submarine landslides. Slide duration is also relatively long, so the coupling between the slide and the surface waves is important. Moreover, this similarity has even a deeper physical sense because the resonant situation for slide-generated tsunamis when the Froude number $F r \approx 1.0$ (cf. Fine et al., 2003) is an analogue of the Proudman resonance for meteorological tsunamis (this question is considered in the following subsection).

Less evident are dissimilarities in the initial spectral content of tsunamis and meteotsunamis. The tsunami source spectrum is more associated with the extension of the source and the mean ocean depth in the source area than with the spectral characteristics of the seismic source itself. In contrast, the open-ocean meteotsunami frequency range is primary associated with the spectrum of the corresponding atmospheric disturbance. Nevertheless, the analysis of specific events in the region of the Balearic Islands (Monserrat et al., 1991a, b) and in the Adriatic Sea (Vilibić and Mihanović, 2003) did not reveal particular peak frequencies in the observed atmospheric pressure spectra but a relatively broad frequency range. It is the resonant mechanism of ocean wave generation that promotes the selection of a specific frequency band of excited ocean waves. In this sense, the resonant nature of meteotsunami generation implies that generation and propagation may not be completely separated. Despite the different generation mechanisms, we may conclude that the initial spectral contents of tsunamis and meteotsunamis have many similarities. Monserrat et al. (1998) for the shelf of Menorca Island reconstructed the transform functions between the atmospheric pressure and open-ocean long waves for several "rissaga" events and restored "source functions" (describing spectral properties of the source area). These functions for atmospherically generated ocean waves looked similar to typical source functions of tsunami waves (cf. Rabinovich, 1997) and occupied approximately the same frequency band $(\sim 1-30 \mathrm{cph})$. Rabinovich and Stephenson (2004), using the data from the same stations at the coast of British Columbia (Pacific coast of Canada), examined source functions for storm-generated ocean waves and for the 2001 Peru tsunami waves and found only minor differences mainly related to the influence of wind waves and swell on stormgenerated long waves.

\subsection{Propagation}

An impulse seismic source generates free long waves propagating with a longwave speed $c=\sqrt{g h}$ determined by the regional bottom depth, $h$. Shallow water areas (e.g. shelves, submarine banks, and ridges) act as wave energy guides. For example, global tsunami propagation models (cf. Titov et al., 
2005) demonstrate that mid-ocean ridges served as waveguides to the 2004 Sumatra tsunami, efficiently transmitting tsunami energy from the source area to far-field regions of the Pacific and Atlantic coasts of North America.

The behavior of "free ocean waves" is independent of the origin of these waves. So, free atmospherically generated waves propagate and transform in absolutely the same way as tsunami waves with the same frequencies. However, free open ocean waves are apparently rarely a source for meteotsunamis. The reason is quite simple: free waves may redistribute the energy as a result of wave interference or interaction with topography but after the initial impulse the waves do not get additional pumping from external energy. For this reason, meteotsunamis are much more often associated with "forced ocean waves", i.e. with waves that interact with the atmospheric pressure and absorb the atmospheric energy during their propagation. The intensity of this "absorption" depends on the proximity of the waves to resonance conditions.

Once again, the situation for atmospherically generated ocean waves is similar to the situation for landslidegenerated tsunami waves. The character and intensity of slide-generated tsunamis, as well as the coupling between the slide and the surface waves, strongly depends on the Froude number, $F r$. For a rigid-body, which moves as an entity with the speed $U$, the Froude number can be defined as

$F r=U / c$,

where $c$ is the local long-wave speed (cf., Pelinovsky and Poplavsky, 1996; Fine et al., 2003). Resonance occurs when these speeds are equal; i.e. when $\mathrm{Fr}=1.0$. The Froude number for submarine landslides plays the same role as the Mach number for high-speed aircrafts. The character of slidegenerated waves is significantly different for "supersonic" $(F r>1.0)$ and "subsonic" $(F r<1.0)$ slide motions (Fine et al., 2003). The supersonic disturbance ( $F r>1.0)$ does not induce free-propagating water waves so that the water displacement (forced wave) is locked to the disturbance and moves with the disturbance speed, almost duplicating its form. When the slide thickness $(D)$ is much smaller than the water depth, we can describe this forced wave roughly as

$\bar{\zeta} \approx \frac{D U^{2}}{U^{2}-c^{2}}=\frac{D}{1-F r^{-2}}$.

The entire situation for atmospherically generated waves is very similar; for these waves we can introduce the Froude number $\mathrm{Fr}$ in the same way (Eq. 3), where now $U$ is the phase speed of the atmospheric disturbance. The atmospherically induced forced wave in the open ocean may be described by the well-known "Proudman expression" (Proudman, 1929):

$\tilde{\zeta} \approx \frac{\Delta \bar{\zeta} c^{2}}{c^{2}-U^{2}}=\frac{\Delta \bar{\zeta}}{1-F r^{2}}$,

where $\Delta \bar{\zeta}=-\Delta P_{a} / \rho g, \Delta P_{a}$ is the atmospheric pressure disturbance and $\rho$ is the water density. Expression (5) for atmospheric waves is quite similar to expression (4) for slidegenerated tsunamis (the small difference between Eqs. (4) and (5) is due to the fact that the slide body is within the body of water; the entire equivalent expressions will be for the adjusted sea levels $\hat{\zeta}=\tilde{\zeta}-\Delta \bar{\zeta}$ ). For the deep ocean, $U \ll c, \quad F r \ll 1.0$ and $\tilde{\zeta} \approx \Delta \bar{\zeta}=-\Delta P_{a} / \rho g$ (the inverted barometer effect). For an extraordinary situation of very fast atmospheric waves and very slow ocean waves $(U \gg c, F r \gg 1.0) \tilde{\zeta} \approx 0$, so no waves are generated. For $U \sim c, \quad F r \sim 1.0$ "Proudman resonance" takes place and the forced ocean wave is significantly amplified. Typical speeds of atmospheric waves are 20 to $40 \mathrm{~m} / \mathrm{s}$, which means that resonance may occur in extensive shallow-water regions of $h=40-160 \mathrm{~m}$ (as it happened in the considered above case of catastrophic waves in the East China Sea on 31 May 1979).

"Greenspan resonance" is analogous to Proudman resonance but for atmospheric waves propagating along the shelf with phase speed $U_{l}$ close to the phase speed $\left(c_{j}, j=0,1 ..\right)$ of one of the first mode edge waves. In the case of Greenspan resonance, the atmospherically generated waves have the form of "forced edge waves". Greenspan resonance is unlikely for both seismic and slide-generated tsunamis but, in general, edge waves play a very important role in the formation of tsunami waves (cf. González et al., 1995).

\subsection{Inundation and harbour resonance}

The major arguments used in the previous sections in favour of the term "meteotsunamis" are their similarity to wellknown seismic tsunamis with precisely the same frequency range. Consequently, the inundation and physical behaviour near the coast are expected to be similar, particularly the effects of shelf/coastal topography on the arriving waves. In fact, one of the main reasons for catastrophic manifestation of tsunamis and meteotsunamis on the coast is their spectral energy content (with periods from a few minutes to two hours), which matches exactly the range of eigen (resonant) periods of medium size inlets, bays and harbours. Therefore, even when tsunamis or meteotsunamis are not energetic enough to affect the open coast, they can be significantly amplified in inner basins due to harbour resonance effects. A famous example of this is the devastation of Port Alberni during the 1964 Alaska catastrophic tsunami; this tsunami did not produce considerable destructive effects along the open coast of British Columbia but caused severe damage (about $\$ 10$ million in 1964 dollars) in Port Alberni due to strong resonance in Alberni Inlet (cf. Henry and Murty, 1995). Similarly, almost all known destructive meteotsunami events (e.g., the meteotsunamis of 31 March 1979 in Nagasaki Bay, Japan and 21 June 1984 in Ciutadella Harbour, Spain) took place inside bays or harbours but not on a nearby open coast.

The spectral properties of tsunami waves in coastal areas are strongly controlled by local resonances in bays or harbours where such waves are observed. Local resonant oscillations from tsunami waves arriving from the open ocean normally have almost the same periods as background oscillations observed at the same site. This was first discovered 
by Japanese scientists over 100 years ago (cf. Honda et al., 1908) and later was confirmed by other studies (cf. Miller, 1972; Soloviev and Kulikov, 1987; Baptista et al. 1992; Rabinovich, 1997, and many others). Tsunami waves from the same event, but recorded at different sites, even at nearby locations, may have very different spectra, while different events recorded at same site have very similar spectra. The same is true for meteotsunamis. In general, long waves approaching the coast (both tsunami and meteotsunamis) tend to become narrow-band processes with specific spectral peaks associated with local topography (see Fig. 1 in Rabinovich, 1997). For this reason, the spectra of both phenomena near the coast are quite similar (Fig. 6). It is therefore difficult to distinguish them from coastal measurements alone, without additional information about their sources. Many "tsunami events" that were originally listed in tsunami catalogues have been subsequently reclassified to be due to atmospheric activity.

González et al. (2001) wrote that "it is not possible to elucidate the source mechanism of the seiche excitations only by inspecting or analysing the sea level records". Their conclusion was based on a statement by Rabinovich and Monserrat (1996) who, after studying catastrophic atmospherically generated rissaga waves on the coast of the Balearic Islands, concluded that "there are no differences between "meteorological" or "seismic" tsunamis with regard to their transformation in the coastal areas or their amplification in bays or harbours". That is why, González et al. (2001) used computed travel times from the seismic and meteorological sources to the observation sites to explain the nature of high-amplitude seiches recorded in Manzanillo and Cabo San Lucas (Pacific coast of Mexico). In fact, there are some possibilities to identify "the source mechanism of the seiche excitations only by analyzing the sea level records" (cf. Rabinovich and Stephenson, 2004). However, such identification is far from trivial because most of the tsunami and meteotsunami properties are very similar.

\section{Some examples of meteotsunamis in the World Ocean}

As it was mentioned above, meteotsunamis are regularly observed at some specific sites that have favourable conditions for the resonant generation of extreme ocean waves. In this section we present some examples of such sites.

\subsection{Nagasaki Bay, Japan (“abiki”)}

Nagasaki Bay is one of the most famous sites for extreme atmospherically generated seiche oscillations. Anomalous harbour oscillations ("abiki waves") in Nagasaki Bay have been known for a long time. In particular, about 100 years ago, Honda et al. (1908) wrote that seiches with wave height more than $0.5 \mathrm{~m}$ are quite common in this bay, and seiches larger than $2 \mathrm{~m}$ are observed now and then. The catastrophic exam-

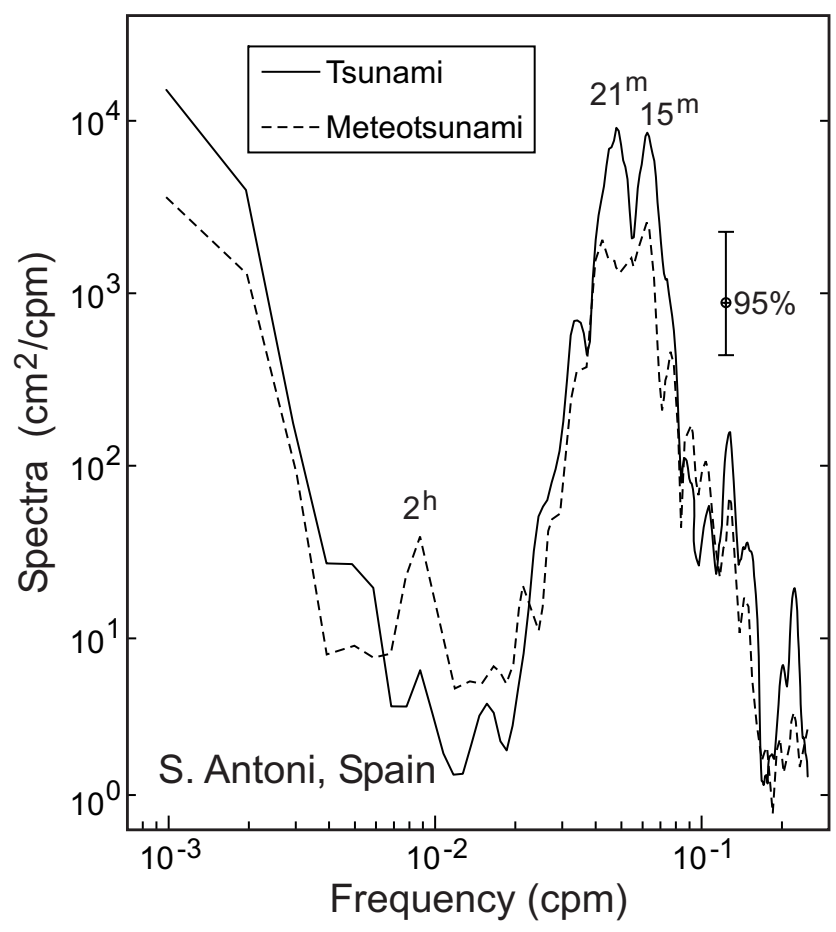

Fig. 6. Sea level spectra for the tsunami of 21 May 2003 and the moderate meteotsunami event of 1 May 2003 recorded at Sant Antoni (Ibiza Island, Spain). Each event has a duration of 4 days with a sampling interval of $2 \mathrm{~min}$ (2880 points). Spectra have been estimated with a Kaiser-Bessel window (cf. Emery and Thomson, 2001) of 128 points with half-window overlaps resulting in 42 degrees of freedom.

ple of "abiki" waves of 31 March 1979 in Nagasaki Bay with wave height of $4.78 \mathrm{~m}$ have already been discussed in Sect. 2 (see Figs. 4 and 5). Another example of destructive "abiki" waves (recorded wave height of $2.09 \mathrm{~m}$ and period of $35 \mathrm{~min}$ ) occurred on 16 March 1988. An estimated wave height of $3.62 \mathrm{~m}$ was observed in the head of the bay (see Fig. 1a in Rabinovich and Monserrat, 1996). Here, we present a few additional statistics on these waves.

According to Honda et al. (1908) and Nakano and Unoki (1962), typical periods of these oscillations are 32-38 min and 22-25 min. "Abiki waves" are mainly observed during unstable atmospheric pressure fields, and sometimes these waves even occur during very calm weather. At the same time, strong cyclones and typhoons passing over Kyushu Island can produce significant oscillations with shorter periods but do not generate "abiki" waves.

Akamatsu (1982) examined 20-year tide gauge records in Nagasaki Bay (1961-1979) and recognized 18 events with wave heights greater than $100 \mathrm{~cm}$. The duration of these oscillations is from 2 to $45 \mathrm{~h}$, but they typically last 36h. Normally, "abiki" waves occur in December-April (the maximum amplitudes occur in March) and never in JulySeptember (the period of typhoons). 


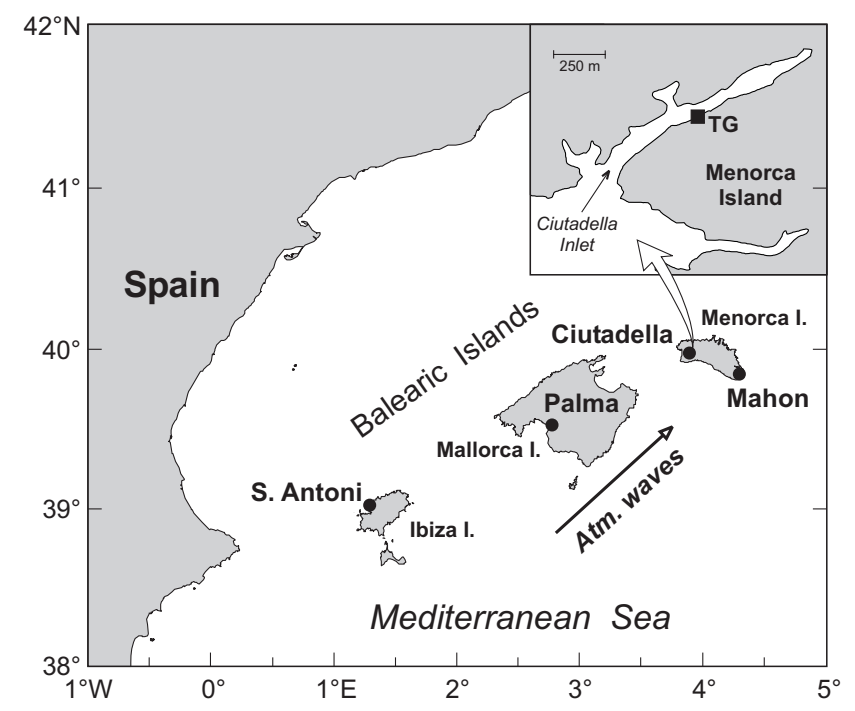

Fig. 7. A map of the Balearic Islands and positions of microbarographs at Palma de Mallorca and Mahon and tide gauges at Sant Antoni and Ciutadella (marked "TG" in the inset). The arrow shows the predominant direction of propagation of the atmospheric waves during "rissaga" events.

\subsection{Longkou Harbour, China}

Extreme seiches are regularly observed in Longkou Harbour located at the mouth of Bohai Bay (Yellow Sea) in China. No other such sites exists in China. Wang et al. (1987) examined 23 years of continuous tide gauge records (1957-1958 and 1961-1981) and selected 137 events when maximum troughto-crest wave heights were greater than $40 \mathrm{~cm}$. Most of these events were found to occur in May-August, while in winter months (January-February) strong seiches were never observed. Longkou Harbour is situated in the same geographical region as Nagasaki Bay and the atmospheric circulation pattern for these two sites is very similar. However, it is interesting to note that the seasonal occurrence of extreme seiches is exactly the opposite. The most probable explanation of this difference is the direction of propagation of atmospheric waves associated with the general monsoon circulation: mainly eastward in winter time (i.e. toward Nagasaki Bay) and westward in summer time (toward Longkou Harbour). The seasonal changes in the intensity of atmospheric processes apparently play a secondary role in meteotsunami formation.

A statistical analysis of strong seiche events in Longkou Harbour indicates significant year-to-year differences in the number of events; the mean number is 6 events per year. The mean duration of the events is from 2 to $4 \mathrm{~h}$ (maximum observed duration was $9 \mathrm{~h}$ ) but the observed periods are not as consistent as in Nagasaki Bay where the most common periods are 85 and $115 \mathrm{~min}$. Over the 23-year observational period, there were 13 events with maximum wave heights more than $100 \mathrm{~cm}$, with the strongest event occurring on 1
September 1980 when the recorded seiche wave height was $293 \mathrm{~cm}$ (Wang et al., 1987; see also Fig. 1b in Rabinovich and Monserrat, 1996).

\subsection{The Balearic Islands, Spain ("rissaga")}

"Rissaga" waves observed on the coast of the Balearic Islands and the eastern Iberian Peninsula are probably the best know and best examined type of meteotsunamis (cf. Fontseré, 1934; Ramis and Jansà, 1983; Tintoré et al., 1988; Monserrat et al., 1991a; Gomis et al., 1993; Garcies et al., 1996; Rabinovich and Monserrat, 1996, 1998; Marcos et al., 2004, among many others). The term "rissaga" was first used by local people to refer to the hazardous oscillations regularly observed in Ciutadella Harbour (Menorca Island) but then extended to similar, although less energetic, oscillations observed in some other bays and inlets of the Balearic Islands (e.g. Porto Colom, Santa Ponça, Pollensa, Sa Rapita, Mahon) and at specific sites along the coast of the Spanish mainland (Tarragona, Barcelona, Valencia)

Ciutadella Inlet is about $1 \mathrm{~km}$ long, $100 \mathrm{~m}$ wide and $5 \mathrm{~m}$ deep. The fundamental period of the inlet (Helmholtz mode) is approximately 10.5-10.6 min (Rabinovich et al., 1999; Liu et al., 2003). At other bays along the coast of the Balearic Islands, the eigen periods and the corresponding dominant periods of "rissaga" waves vary from 5 to $45 \mathrm{~min}$. Due to the particular geometry of Ciutadella Inlet, it has a large $Q$ factor, which results in significant resonant amplification of longwave oscillations arriving from the open sea. Another important factor is the shape and the depth of the southeastern shelf of the Balearic Islands (Fig. 7) which is conducive to Proudman resonance type generation of intensive long ocean waves by travelling atmospheric disturbances. Thus, the "rissaga" waves in Ciutadella Harbour (located at the head of the inlet) are produced by a combination of two resonant effects: (1) resonantly induced strong long waves propagating over the shelf and arriving at the mouth of Ciutadella Inlet; and (2) the resonant amplification of the arriving waves in the inlet itself.

Fontseré (1934), in the first scientific paper on extreme seiches for the Catalan coast, showed that these seiches always occur from June to September and first suggested their atmospheric origin. This origin of "rissaga" waves was supported by Ramis and Jansà (1983) and Jansà (1986) based on observed oscillations on the Balearic Islands. These authors also defined some typical synoptic situations and other weather aspects normally associated with "rissaga" events.

The atmospheric source of "rissaga" is now well established (cf. Tintoré et al., 1988; Garcies et al., 1996; Monserrat et al., 1991a, 1998). During late spring and summer, meteorological conditions in the western Mediterranean are favourable for the formation of high frequency atmospheric pressure disturbances with parameters promoting the generation of "rissaga" waves. These conditions include the entrance of warm air from the Sahara at near-surface levels, 


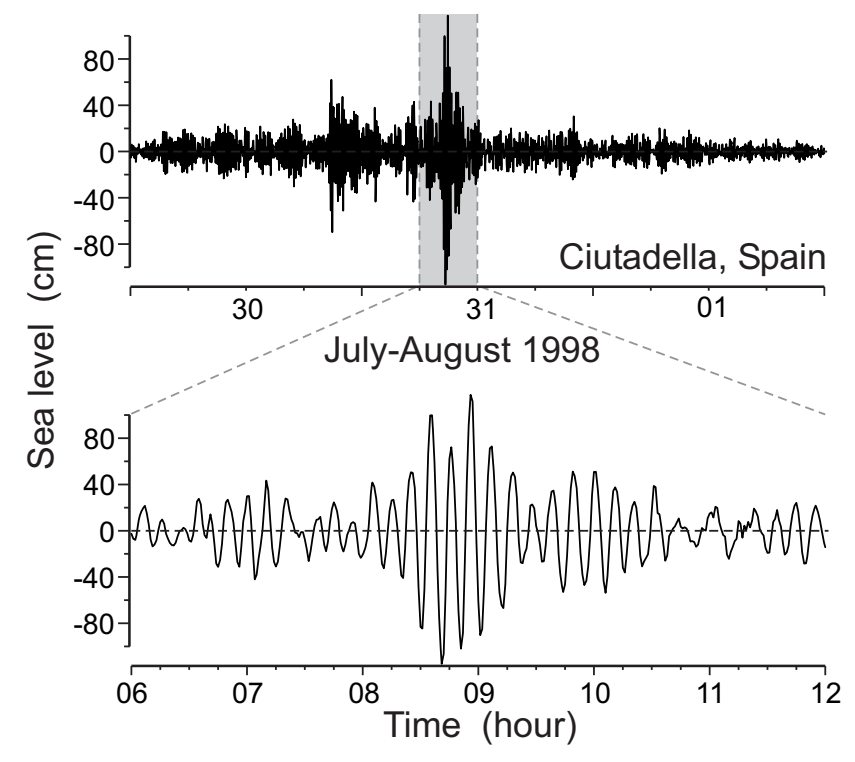

Fig. 8. The strong "rissaga" event recorded in Ciutadella Inlet (Menorca Island, Spain) on 31 July 1998. The inlet and the position of the tide gauge are shown in the inset to Fig. 7.

and relatively strong middle level winds from the southwest (SW). When this synoptic meteorological situation exists, trains of atmospheric pressure gravity waves (with periodicities in the range of minutes) are reported travelling from SW to NE (Monserrat et al., 1991b). If these atmospheric pressure disturbances propagate with a phase speed of about $22-30 \mathrm{~m} / \mathrm{s}$ and direction from SW to NE, the resonant conditions take place on the southeastern shelf of Mallorca Island and dynamic energy of atmospheric waves is efficiently transferred into the ocean waves. When these waves reach the coast of Menorca Island, they may generate significant (and sometimes even hazardous) seiche oscillations inside Ciutadella and some other inlets due to the harbour resonance (Fig. 8).

As is typical for the western Mediterranean, tides in Ciutadella, are relatively small $(\sim 20 \mathrm{~cm})$. Consequently, harbour structures and ropes tying the boats to the harbour walls are not designed to accommodate large sea level changes. Significant "rissaga" waves $(\sim 1 \mathrm{~m})$ normally occur a few times per year (always in summer or during September). These events normally produce only some small floods in the area without additional negative consequences (Rabinovich and Monserrat, 1996). Destructive "rissagas" (>2 m) occur every 4-5 years. The "rissaga" of 21 June 1984, with wave heights of more than $4 \mathrm{~m}$, was the most catastrophic event ever reported; more than 300 boats and yachts were badly damaged (Jansà, 1986; Rabinovich and Monserrat, 1996).

Recently, on 15 June 2006 at 20:50 local time (18:50 UTC), Ciutadella Harbour was affected by the most dramatic "rissaga" event of the last 20 years (Monserrat et al., 2006). A sudden first negative (ebb) wave of more than
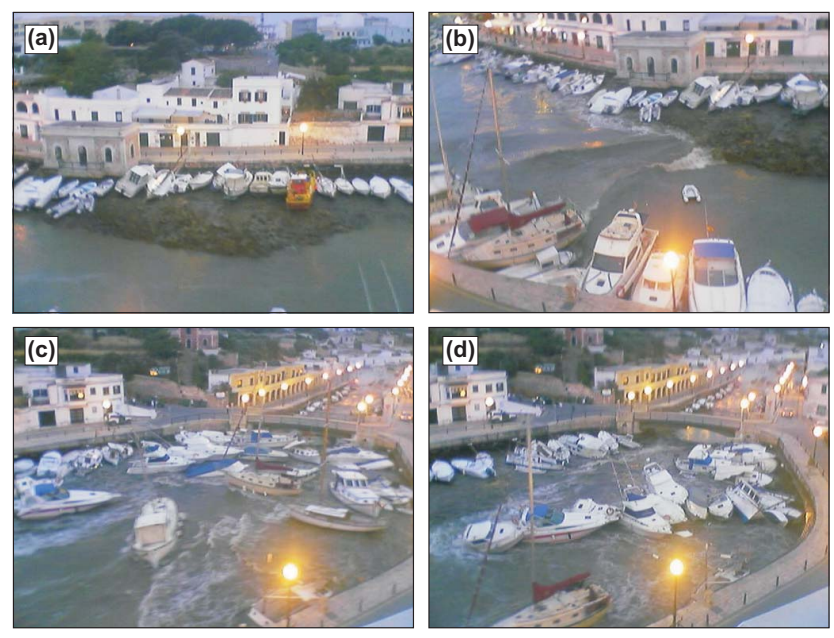

Fig. 9. Photographs taken during the strong rissaga event of 15 June 2006 at Ciutadella Harbour. (a) After the sudden first negative wave $(\sim-4 \mathrm{~m})$, most of the boats broke free from their moorings and were left high and dry on the harbour bottom. (b) A few minutes later, the water re-entered the harbour and the boats were freely dragged by the current. (c) and (d) More than 40 boats were severely damaged.

$4 \mathrm{~m}$ was reported by local witnesses causing the catastrophic drying of a significant part of the harbour. As a result, most of the boats in the harbour broke free from their moorings on the harbour walls and were freely dragged by the current when the water re-entered the harbour only a few minutes later. More than 40 boats were sunk or severely damaged (Fig. 9) with the total economic loss estimated to be in order of tens of millions of euros. This event was undoubtedly associated an abrupt atmospheric pressure jump passing over the Balearic Islands (Fig. 10) The atmospheric pressure dramatically increased in Palma de Mallorca by almost 7 mbar in only half an hour, and more impressively, the last 5 mbar increase occurred in less than $10 \mathrm{~min}$ (Fig. 10). This pressure jump travelled from the SW to NE, first being recorded at Palma de Mallorca (Mallorca Island) at 19:50 local time (17:50 UTC) and then about $77 \mathrm{~min}$ later, at Mahon (Menorca Island) at 21:07 (19:07 UTC). Assuming the distance along the expected wave track between these two sites is about $115 \mathrm{~km}$, we obtain an estimated wave speed of roughly $25 \mathrm{~m} / \mathrm{s}$. As mentioned above, the wave direction and propagation speed are conducive to producing a resonant response on the Mallorca shelf and the following observed extreme seiches (rissaga waves) in Ciutadella Inlet. Unfortunately, there were no working tide gauges in the inlet during the event, although witness reports indicate the same period of oscillations $(\sim 10.5 \mathrm{~min})$ as was observed in this inlet during other rissaga events (cf. Fig. 8). 


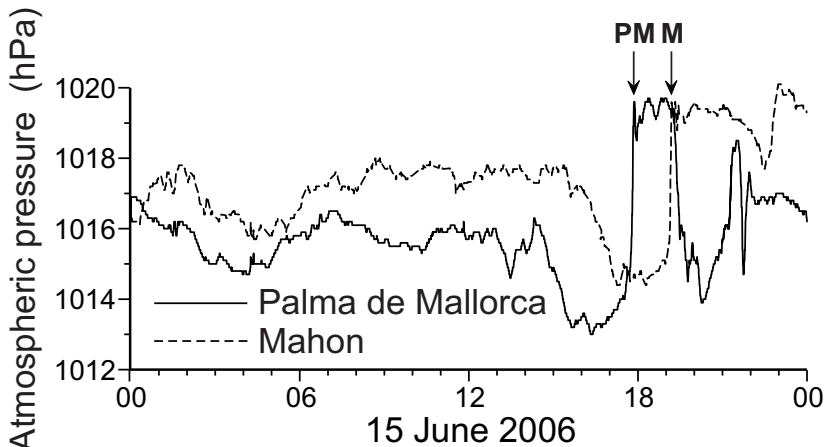

Fig. 10. Atmospheric pressure records from Palma de Mallorca (Mallorca Island) and Mahon (Menorca Island) on 15 June 2006. The arrows "PM" and " $M$ " indicate the strong jump in atmospheric pressure that occurred at Palma de Mallorca at approximately 17:50 UTC and at Mahon at 19:07 UTC, respectively. Positions of the stations are shown in Fig. 7.

\subsection{Adriatic Sea}

The North Adriatic is an extensive shallow-shelf region almost $300 \mathrm{~km}$ long, with mean depths of 20 to $100 \mathrm{~m}$. This region is favourable for open-sea Proudman resonance; however, damaging meteotsunamis have never been observed in this region due to the absence of bays or harbours with large Q-factors. Nevertheless, significant seiche oscillations (0.5$1 \mathrm{~m})$ have been repeatedly recorded in this region, in particular in the Gulf of Trieste and the Gulf of Venice (Caloi, 1938; Greco et al., 1957; Defant, 1961; Wilson, 1972).

The region best known for extreme meteotsunami events is the eastern part of the middle Adriatic where there are a number of islands, channels and funnel-shaped bays and harbours. Tides in this region are much smaller than in the North Adriatic (about $20-30 \mathrm{~cm}$ in comparison with $1 \mathrm{~m}$ in the area of Trieste) which brings a greater risk for the coastal areas and infrastructure in the middle Adriatic, not accustomed to high sea level oscillations. The strongest meteotsunami event occurred on 21 June 1978 in the Vela Luka Bay (Korčula Island), when a train of 15-min ocean waves hit the port. The maximum trough-to-crest wave height was estimated by eyewitnesses to be about $6 \mathrm{~m}$ at the head of the bay (Hodžić, 1979/1980) (Fig. 11). This meteotsunami caused significant flooding and severely damaged the port and boats inside the harbour. Although there were no tide gauges in the bay, Orlić (1980) was able to show that these waves were induced by an atmospheric disturbance that propagated from southwest to northeast with a speed of $22 \mathrm{~m} / \mathrm{s}$ (according to the barograph records), suggesting that the large amplitudes of ocean waves in the port were due to the resonant coupling of this disturbance with the open-sea waves.

A very similar disastrous event occurred in this region on 27 June 2003. The strongest effects occurred in two other funnel-shaped bays: Stari Grad Bay (Hvar Island) and Mali

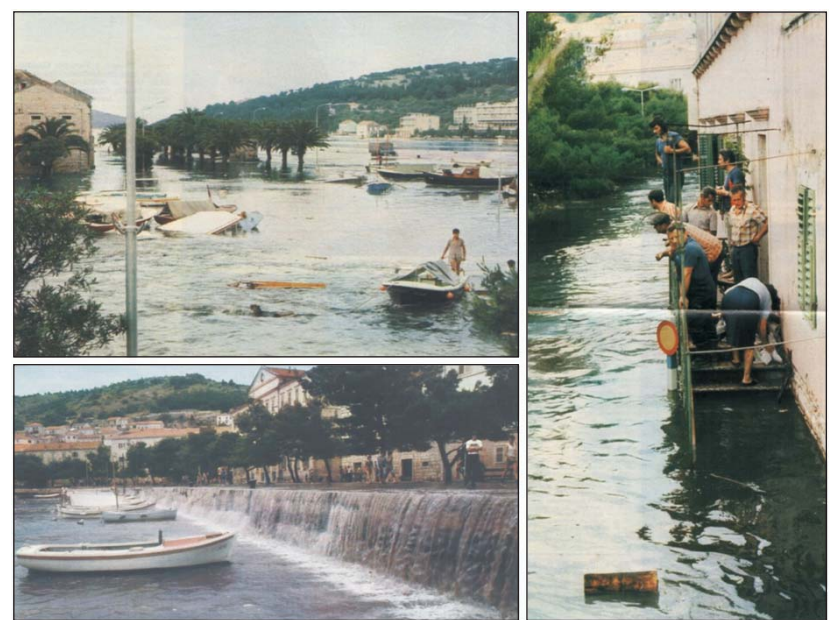

Fig. 11. Photographs of Vela Luka Bay (Croatia) taken during the meteotsunami event of 21 June 1978.

Ston Bay, located between the Dalmatian mainland and the Pelješac Peninsula (Fig. 12). According to eyewitness reports that came from Stari Grad, the peak oscillation amplitude was about $1.3 \mathrm{~m}$, resulting in flooding of a part of the town. The reports from Mali Ston indicate destructive reversing currents associated with this event that swept away shellfish farms located in the constrictions of this bay (Fig. 13).

Although there were no measurements specifically in these two bays, digital tide gauge data were available for several nearby sites (Fig. 14a). These data were used to examine the event and to verify a barotropic numerical model used to simulate atmospherically induced waves in this region (Vilibić et al., 2004). The air-pressure sine-like disturbance ranged up to $8 \mathrm{hPa}$ was recorded by a number of microbarographs (Fig. 14b), which enabled the authors to estimate the disturbance speed $(22 \mathrm{~m} / \mathrm{s})$ and direction $\left(108^{\circ}\right.$ True $)$. This disturbance resonantly coupled with surface ocean waves in the $50 \mathrm{~m}$ deep sea (the typical depth of the external shelf in this region). The numerically simulated sea levels and currents were in good agreement with the recorded data and witness reports.

One of the interesting questions is why the 1978 meteotsunami was observed in Vela Luka Bay but not in Stari Grad Bay and, vice versa, why the 2003 meteotsunami affected Stari Grad and Mali Ston bays but not Vela Luka Bay. The estimated speed of the atmospheric disturbances was the same for both events $(22 \mathrm{~m} / \mathrm{s})$; however the directions of the 1978 and 2003 atmospheric disturbances were slightly different. Apparently it was this difference in directions that was responsible for the different amplification of harbour oscillations for these two events. Another possible reason is the difference in the fundamental resonant periods of the two bays: 15 min for Vela Luka Bay (Orlić, 1980) and $10.6 \mathrm{~min}$ for Stari Grad Bay (Vilibić et al., 2004). Also, the opensea waves arriving at the entrances of the bays might have 


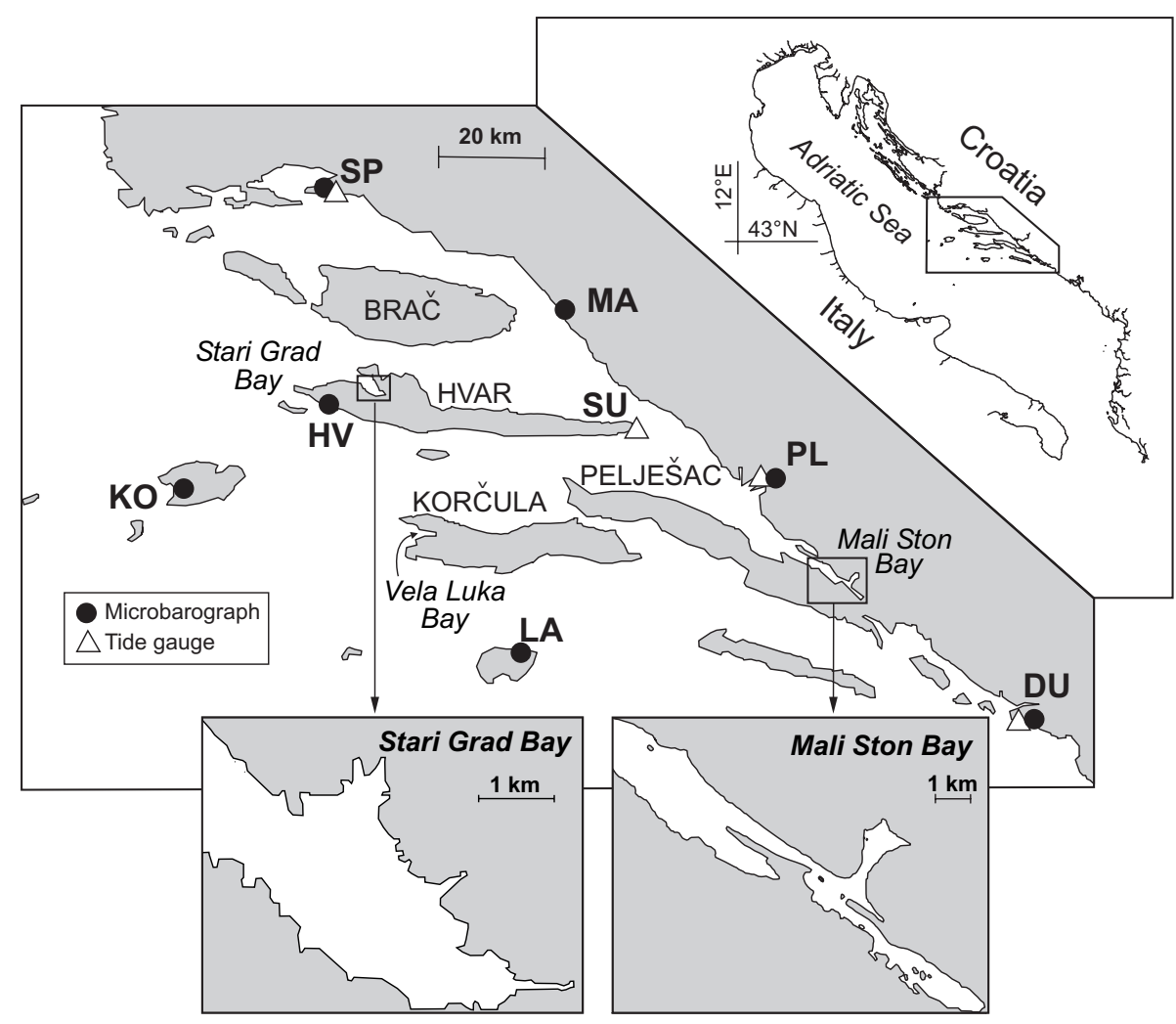

Fig. 12. A map showing the eastern Adriatic coastal area, including enlarged maps of Stari Grad and Mali Ston bays. Circles denote microbarographs ("KO", Komiža; "HV”, Hvar; "SP", Split; "MA", Makarska; "PL", Ploče; "LA", Lastovo; and "DU”, Dubrovnik), while triangles mark tide gauges (“SU”, Sućuraj; "SP”, "PL”, and "DU”) (adopted from Vilibić et al., 2004).

possessed different spectral energy contents due to the spectral differences of the 1978 and 2003 disturbances. Unfortunately, the poor quality of the 1978 barograph records make it impossible to provide a more thorough examination of this question.

\section{Discussion and conclusions}

Examples presented in this study demonstrate the strong similarity between seismic tsunamis and meteotsunamis: they have the same periods, same spatial scales, similar physical properties and affect the coast in a comparable destructive way. Moreover, some specific features of meteotsunamis make them very similar to landslide-generated tsunamis. In particular, the key generation factor for both phenomena is the coupling between the moving disturbance (landslide or atmospheric) and the surface ocean waves. The generation efficiency strongly depends on the Froude number, $F r=U / c$, where $U$ is the speed of the forcing factor (landslide or atmospheric disturbance) and $c$ is the surface wave speed. Resonance occurs when $F r \sim 1.0$. From this point of view, to use the term "meteorological tsunami" (or "meteotsunami") for "tsunami-like waves generated by meteorological factors" is

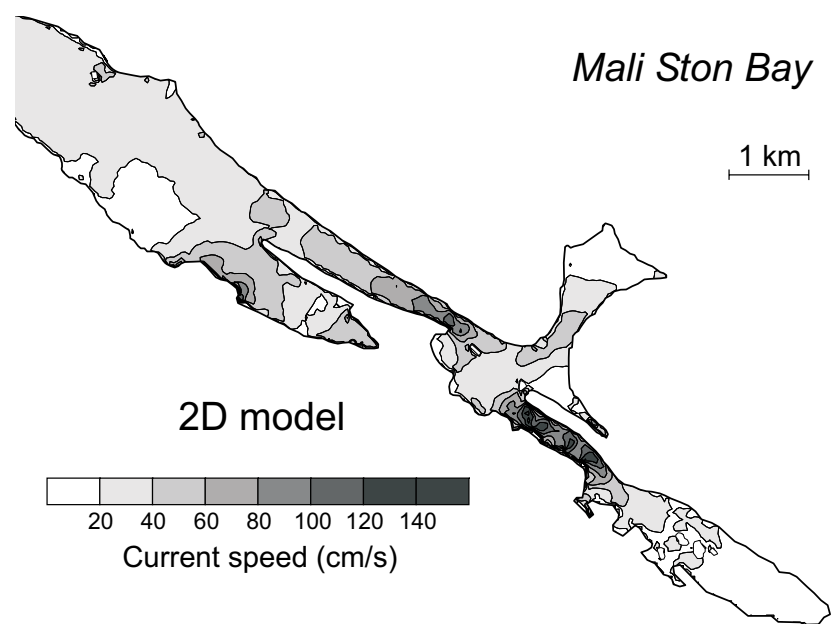

Fig. 13. Maximum current speed modelled for Mali Ston Bay for the time of the meteotsunami event of 27 June 2003.

no less logical than to use the term "landslide tsunamis" for "tsunami-like waves generated by submarine landslides".

One of the important reasons to consider slide-generated waves as "tsunamis" is that in many cases submarine 

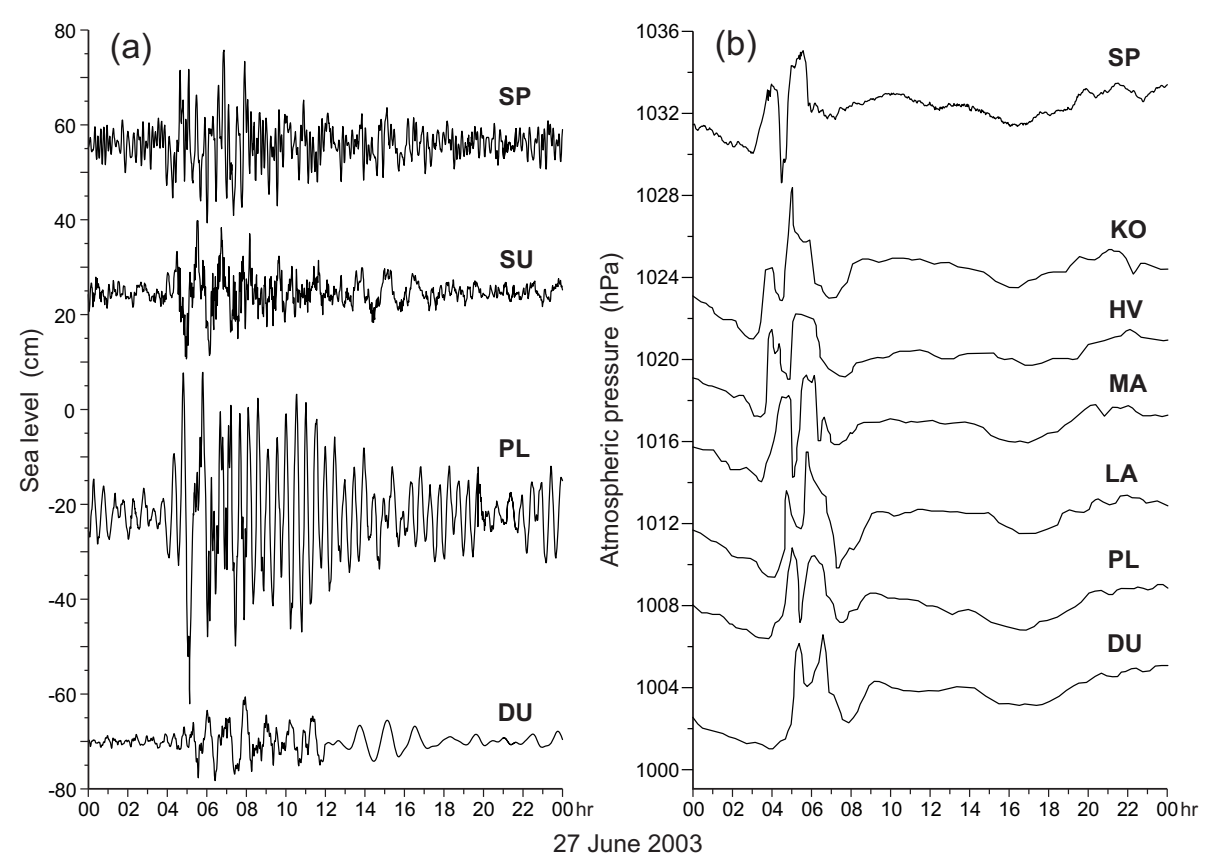

Fig. 14. (a) The high-frequency component of the sea level time series for Split, Sućuraj, Ploče and Dubrovnik. Low-frequency oscillations have been removed by a high-pass digital filter with a cut-off period of $2 \mathrm{~h}$. (b) High-resolution air pressure oscillations measured at a number of microbarographs during the meteotsunami event of 27 June 2003.

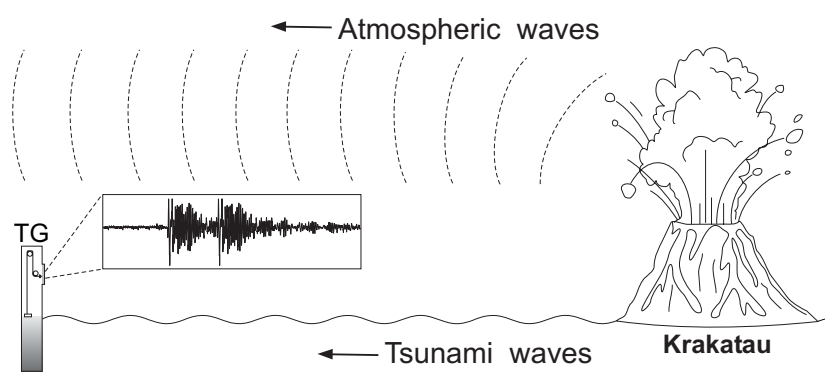

Fig. 15. A sketch illustrating the generation of longwave sea level oscillations at remote tide gauges after the 1883 Krakatau explosion.

landslides are the secondary effects of earthquakes and, in fact, it is difficult to recognize what is the actual source of tsunami waves: a submarine earthquake, an associated landslide, or both. We can present a similar paradoxical example of a meteorological tsunami being a secondary effect of a volcanic explosion when it is difficult to recognize the actual source of the observed waves. This example is related to the famous global tsunami caused by the Krakatau Volcano (Indonesia) explosion of 27 August 1883 (cf. Murty, 1977; Bryant, 2001). The 1883 Krakatau tsunami was recorded by 35 tide gauges in the Indian, Pacific and Atlantic oceans, including gauges in Le Havre (France), Kodiak Island (Alaska) and San Francisco (California) (cf. Pelinovsky et al., 2005). However, according to a common opinion (cf. Ewing and
Press, 1955; Garrett, 1970), tsunami waves recorded at farfield sites originated from coupling between the ocean surface and the explosion-induced atmospheric waves (that circuited the globe three times - see Murty, 1977) rather than from direct water waves propagated from the source area (Fig. 15). The problem is the mismatch in time between observed and expected tsunami waves: the waves in the Pacific and Atlantic were recorded too early for long ocean waves to arrive at these sites but in good agreement with atmospheric sound waves $(U \sim 340 \mathrm{~m} / \mathrm{s})$ to arrive (Garrett, 1970). Therefore, the near-field records of the 1883 Krakatau tsunami were apparently related to real surface ocean waves arriving from the source area whereas the records from intermediately located tide gauges included some mixture of directly arriving ocean waves and atmospherically-generated waves. Farfield records were associated purely with atmospheric waves. From an orthodox point of view, the term "tsunami" cannot even be used for the latter. However, it is much easier to call all these waves "tsunamis", keeping in mind the actual generation mechanism of these waves. Certainly, we do not consider this example as a major argument; this event was exceptional and most of meteorological tsunamis have nothing to do with any seismic or volcanic activity. Nevertheless, this example clearly indicates the very close relationship between tsunamis and meteotsunamis.

Normally, tide gauge records of harbour oscillations generated by atmospheric disturbances and by a seismic source look very similar, so it is unclear whether the origin of these oscillations could be detected from analysis of tide gauge 
data. However, the clear visible similarity of tsunami and meteotsunami records is related to the same resonance influence of the local topography and does not mean that their sources are similar. In fact, the particular properties of the sources can be used to distinguish between these two phenomena. Rabinovich (1997) and Monserrat et al. (1998) suggested a simple approach to analyse tsunamis/meteotsunamis and to reconstruct their spectral source characteristics. The comparative analysis of the event and background spectra allows separating the source and topography effects. Eliminating the influence of topography and restoring the source, it is possible to identify these phenomena and gain insight into their nature. In particular, Rabinovich and Stephenson (2004) examined in this way the tide gauge records for the coast of British Columbia and demonstrated some found differences between tsunami and meteotsunamis reconstructed source functions.

As was shown by Monserrat et al. (1997), the source function of rissaga waves has a specific shape, distinguishable from any other types of oscillations. Apparently, the source functions of seismic and meteorological tsunamis are different, but more observational data are necessary to support this supposition.

In conclusion, we should mention one very important physical difference between disastrous seismic tsunamis and meteotsunamis. The former are normally generated by major earthquakes. Such earthquakes are relatively infrequent events and this is the reason why major tsunamis are quite rare. The topographic resonant effects can locally strongly amplify arriving tsunami waves causing catastrophic effects (like in Port Alberni in 1964); however, tsunami waves can be energetic enough to create severe damage along the entire coast even without specific resonance (the 2004 Sumatra tsunami is an obvious example, cf. Titov et al., 2005; Rabinovich et al., 2006). In contrast, strong atmospheric disturbances of various types (passing fronts, squalls, and trains of atmospheric waves) are common. Nevertheless, strong effects (high-energetic ocean waves) occur only for very specific combinations of resonant effects. The rareness of such combinations is the main reason why major meteotsunamis are exceptional and observed only at a limited number of sites in the World Ocean.

Acknowledgements. The atmospheric pressure records from Palma de Mallorca and Mahon during the strong rissaga event of 15 June 2006 were kindly provided by A. Jansà from the "Centre Meteorològic Territorial a les Illes Balears" (INM), Palma de Mallorca, Spain. We further thank R. Thomson (Institute of Ocean Sciences, Sidney, BC) for his advice and thorough editing the manuscript and P. Kimber (Sidney, BC) for drawing the final versions of the figures. For A. B. Rabinovich partial financial support was provided by the Russian Federation through RFBR Grants 05-05-64585 and 06-05-08108, while the work of I. Vilibic was supported by the Ministry of Science, Education and Sports of the Republic of Croatia.
Edited by: S. Tinti

Reviewed by: one referee

\section{References}

Airy, G. B.: On the tides on Malta, Philos. Trans. Roy. Soc. London, 169, 123-138, 1878.

Akamatsu, H.: On seiches in Nagasaki Bay, Pap. Meteorol. Geophys. (in Japanese), 33(2), 95-115, 1982.

Baptista, M. A., Miranda, P., and Victor, L. M.: Maximum entropy analysis of Portuguese tsunami data: The tsunamis of 28.02.1969 and 26.05.1975, Sci. Tsunami Hazards, 10(1), 9-20, 1992.

Bryant, E.: Tsunami: The Underrated Hazard, Cambridge University Press, Cambridge, 350 p, 2001.

Caloi, P.: Sesse dell' alto Adriatico con particolare riguardo al Golfo di Trieste, R. Comit. Talass. Ital. - Mem. (in Italian), 247, 1-39, 1938.

Candela, J., Mazzola, S., Sammari, C., Limeburner, R., Lozano, C. J., Patti, B., and Bonnano, A.: The "Mad Sea" phenomenon in the Strait of Sicily, J. Phys. Oceanogr., 29, 2210-2231, 1999.

Colucci, P. and Michelato, A.: An approach to study of the 'Marubbio' phenomenon, Boll. Geofis. Theor. Appl., 13(69), 3-10, 1976.

Defant, A.: Physical Oceanography, Vol.2, Pergamon Press, Oxford, 1961.

Donn, W. L.: The Great Lakes storm surge of May 5, 1952, J. Geophys. Res., 64(2), 191-198, 1959.

Donn, W. L. and Balachandran, N. K.: Coupling between a moving air-pressure disturbance and the sea surface, Tellus, 21(5), 701706, 1969.

Donn, W. L. and Ewing, M.: Stokes' edge waves in Lake Michigan, Science, 124, 1238-1242, 1956.

Donn, W. L. and McGuinness, W. T.: Air-coupled long waves in the ocean, J. Meteorology, 17(5), 515-521, 1960.

Douglas, C. K. M.: The line-squall and Channel wave of July 20th, 1929, Meteorol. Magazine, 64, 187-189, 1929.

Dragani, W. C., Mazio, C. A., and Nuñez, M. N.: Sea level oscillations in coastal waters of the Buenos Aires province, Argentina, Cont. Shelf Res., 22, 779-790, 2002.

Drago, A. F.: A study on the sea level variations and the 'Milghuba' phenomenon in the coastal waters of the Maltese Islands, Ph.D. thesis, University of Southampton, 1999.

Emery, W. J. and Thomson, R. E.: Data Analysis Methods in Physical Oceanography, Second and revised edition, Elsevier, New York, 638 p., 2001.

Ewing, M. and Press, F.: Tide gauge disturbances from the great eruption of Krakatoa, Trans. Amer. Geophys. Un., 36(1), 53-60, 1955.

Ewing, M., Press, F., and Donn, W. J.: An explanation of the Lake Michigan wave of 26 June 1954, Science, 120, 684-686, 1954.

Fine, I. V., Rabinovich, A. B., Thomson, R. E., and Kulikov, E. A.: Numerical modeling of tsunami generation by submarine and subaerial landslides, in: Submarine Landslides and Tsunamis, edited by: Yalçiner, A. C., Pelinovsky, E. N., Synolakis, C. E., and Okal, E., NATO Adv. Series, Kluwer Acad. Publ., Dorderecht, 69-88, 2003.

Fine, I. V., Rabinovich, A. B., and Thomson, R. E.: The dual source region for the 2004 Sumatra tsunami, Geophys. Res. Lett., 32, L16602, doi:10.1029/2005GL023521, 2005. 
Fontseré, E.: Les 'seixes de la costa catalana. Servei Meteorològic de Catalunya, Notes d'Estudi, 58 (in Catalan), 1934.

Garcies, M., Gomis, D., and Monserrat, S.: Pressure-forced seiches of large amplitude in inlets of the Balearic Islands. Part II: Observational study, J. Geophys. Res., 101(C3), 6453-6467, 1996.

Garrett, C. J. R.: A theory of the Krakatoa tide gauge disturbances, Tellus, 22(1), 43-52, 1970.

Gomis, D., Monserrat, S., and Tintoré, J.: Pressure-forced seiches of large amplitude in inlets of the Balearic Islands, J. Geophys. Res., 98, 14 437-14 445, 1993.

González, F. I., Satake, K., Boss, E. F., and Mofjeld, H.: Edge wave and non-trapped modes of the 25 April 1992 Cape Mendocino tsunami, Pure Appl. Geohys., 144, 409-426, 1995.

González, J. I., Fareras, S. F., and Ochoa, J.: Seismic and meteorological tsunami contributions in the Manzanillo and Cabo San Lukas seiches, Marine Geodesy, 24, 219-227, 2001.

Goring, D. G.: Observations of long waves around New Zealand, Long Waves Symp., Thessaloniki, Greece, 237-245, 2003.

Goring, D. G.: Rissaga (long-wave events) on New Zealand's eastern seaboard: A hazard for navigation, Proc. 17th Australasian Coastal Ocean Eng. Conf., 20-23 September 2005, Adelaide, Australia, 137-141, 2005.

Gossard, E. E. and Hooke, B. H.: Waves in Atmosphere, Elsevier, New York, 456 p, 1975.

Gossard, E. E. and Munk, W. H.: On gravity waves in the atmosphere, J. Meteorol., 11, 259-269, 1954.

Greco, L., Calci, P., and Visioli, F.: The effects of long period waves in ports and their origin, Proc. 19th Int. Navigation Congr., Sec.II, Commun. 1 (in French), 119-143, 1957.

Greenspan, H. P.: The generation of edge waves by moving pressure disturbances, J. Fluid Mech., 1, 574-592, 1956.

Harris, D. L.: The effect of a moving pressure disturbance on the water level in a lake, Meteorol. Monogr., 2(10), 46-57, 1957.

Henry, R. F. and Murty, T. S.: Tsunami amplification due to resonance in Alberni Inlet: Normal modes, in: Tsunami: Progress in Prediction, Disaster Prevention and Warning, edited by: Tsuchiya, Y. and Shuto, N., Kluwer, Dordrecht, 117-128, 1995.

Hibiya, T. and Kajiura, K.: Origin of 'Abiki' phenomenon (kind of seiches) in Nagasaki Bay, J. Oceanogr. Soc. Japan, 38, 172-182, 1982.

Hodžić, M.: Occurrences of exceptional sea-level oscillations in the Vela Luka Bay, Priroda (in Croatian), 68(2-3), 52-53, 1979/1980.

Honda, K., Terada, T., Yoshida, Y., and Isitani, D.: An investigation on the secondary undulations of oceanic tides, J. College Sci., Imper. Univ. Tokyo, 108 p, 1908.

Irish, S. M.: The prediction of surges in the southern basin of Lake Michigan - Part II, Mon. Wea. Rev., 93(5), 282-291, 1965.

Jansà, A.: Respuesta marina a perturbaciones mesometeorológicas: la 'rissaga' de 21 de junio de 1984 en Ciutadella (Menorca), Rev. Meteorologia, junio (in Spanish), 5-29, 1986.

Jiang, L. and LeBlond, P. H.: The coupling of a submarine slide and the surface waves which it generates, J. Geophys. Res., 97(C8), 12 731-12 744, 1992.

Lander, J. F, Lockridge, P. A., and Kozuch, M. J.: Tsunamis affecting the West Coast of the United States 1806-1992, U.S. Dep. Commerce, NOAA, National Geophysical Data Center, Boulder, USA, 242 p, 1993.

Liu, P. L.-F., Monserrat, S., Marcos, M., and Rabinovich, A. B.:
Coupling between two inlets: Observation and modeling, J. Geophys. Res., 108(C3), 3069, doi:10.1029/2002JC001478, 2003.

Marcos, M., Liu, P. L.-F., and Monserrat, S.: Nonlinear resonant coupling between two adjacent bays, J. Geophys. Res., 109, C05008, doi:10.1029/2003JC002039, 2004.

Mei, C. C.: The Applied Dynamics of Ocean Surface Waves, World Scientific, London, 740 p., 1992.

Mercer, D., Sheng, J., Greatbatch, R. J., and Bobanović, J.: Barotropic waves generated by storms moving rapidly over shallow water, J. Geophys. Res., 107(C10), 3152, doi:10.1029/2001JC001140, 2002.

Metzner, M., Gade, M., Hennings, I., and Rabinovich, A. B.: The observation of seiches in the Baltic Sea using a multi data set of water levels, J. Mar. Syst., 24, 67-84, 2000.

Miles, J. W.: Harbor seiching, Ann. Rev. Fluid Mech., 6, 17-36, 1974.

Miles, J. and Munk, W.: Harbor paradox, J. Waterways Harbor Division, ASCE, 87, 111-130, 1961.

Miller, G. R.: Relative spectra of tsunamis, Publ. HIG 72-8, 7 p., Hawaii Inst Geophys., Honolulu, 1972.

Monserrat, S., Ibberson, A., and Thorpe, A. J.: Atmospheric gravity waves and the "rissaga" phenomenon, Quart. J. Roy. Meteorol. Soc., 117, 553-570, 1991a.

Monserrat, S., Ramis, C., and Thorpe, A. J.: Large-amplitude pressure oscillations in the Western Mediterranean, Geophys. Res. Lett., 18, 183-186, 1991b.

Monserrat, S., Rabinovich, A. B., and Casas, B.: On the reconstruction of the transfer function for atmospherically generated seiches, Geophys. Res. Lett., 25(12), 2197-2200, 1998.

Monserrat, S., Gomis, D., Jansà, A., and Rabinovich, A. B.: The rissaga of 15 June 2006 in Ciutadella Harbour, Menorca Island, Spain, Tsunami Newsletter, 38(2), 5-7, 2006.

Murty, T. S.: Seismic Sea Waves - Tsunamis, Bull. Fish. Res. Board Canada, 198, Ottawa, 337 p, 1977.

Nakano, M. and Unoki, S.: On the seiches (secondary undulations of tides) along the coast of Japan, Records Oceanogr. Works Japan, Spec. No. 6, 169-214, 1962.

Nomitsu, T.: A theory of tsunamis and seiches produced by wind and barometric gradient, Mem. Coll. Sci. Imp. Univ. Kyoto, A 18(4), 201-214, 1935.

Orlić, M.: About a possible occurrence of the Proudman resonance in the Adriatic, Thalassia Jugoslavica, 16(1), 79-88, 1980.

Papadopoulos, G. A.: On some exceptional seismic (?) sea-waves in the Greek archipelago, Sci. Tsunami Hazards, 11, 25-34, 1993.

Pelinovsky, E. and Poplavsky, A.: Simplified model of tsunami generation by submarine landslides, Phys. Chem. Earth, 21(12), 1317, 1996.

Pelinovsky, E., Choi, B. H., Stromkov, A., Didenkulova, I., and Kim, H. S.: Analysis of tide-gauge records of the 1883 Krakatau tsunami, in: Tsunamis: Case Studies and Recent Developments, edited by: Satake, K., Springer, Dordrecht, 57-77, 2005.

Platzman, G. W.: A numerical computation of the surge of 26 June 1954 on Lake Michigan, Geophysica, 6(1), 407-438, 1958.

Platzman, G. W.: The prediction of surges in the southern basin of Lake Michigan - Part I, Mon. Wea. Rev., 93(5), 275-281, 1965.

Proudman, J.: The effects on the sea of changes in atmospheric pressure, Geophys. Suppl. Mon. Notices R. Astr. Soc., 2(4), 197209, 1929.

Pugh, D. T.: Tides, Surges and Mean Sea-Level, J. Wiley, Chich- 
ester, 472 p., 1987.

Rabinovich, A. B.: Long Ocean Gravity Waves: Trapping, Resonance, and Leaking, Gidrometeoizdat, St. Petersburg, 325 p. (in Russian), 1993.

Rabinovich, A. B.: Spectral analysis of tsunami waves: Separation of source and topography effects, J. Geophys. Res., 102(C6), 12 663-12 676, 1997.

Rabinovich, A. B. and Monserrat, S.: Meteorological tsunamis near the Balearic and Kuril Islands: Descriptive and statistical analysis, Nat. Hazards, 13(1), 55-90, 1996.

Rabinovich, A. B. and Monserrat, S.: Generation of meteorological tsunamis (large amplitude seiches) near the Balearic and Kuril Islands, Nat. Hazards, 18(1), 27-55, 1998.

Rabinovich, A. B., Monserrat, S., and Fine, I. V.: Numerical modeling of extreme seiche oscillations in the region of the Balearic Islands, Oceanology, 39(1), 16-24, 1999.

Rabinovich, A. B. and Stephenson, F. E.: Longwave measurements for the coast of British Columbia and improvements to the tsunami warning capability, Nat. Hazards, 32(3), 313-343, 2004.

Rabinovich, A. B., Thomson, R. E., and Stephenson, F. E.: The Sumatra Tsunami of 26 December 2004 as observed in the North Pacific and North Atlantic Oceans, Surveys in Geophysics, 27, 647-677, 2006.

Raichlen, F.: Harbor resonance, in: Estuary and Coastline Hydrodynamics, edited by: Ippen, A. T., McGraw Hill Book Comp., New York, 281-340, 1966.

Ramis, C. and Jansà, A.: Condiciones meteorológicas simultáneas a la aparición de oscilaciones del nivel del mar de amplitud extraordinaria en el Mediterráneo occidental, Rev. Geofísica (in Spanish), 39, 35-42, 1983.

Soloviev, S. L. and Kulikov, E. A.: Spectral analysis of mareograms from Urup tsunamis of 13 and 20 October 1963, Sci. Tsunami Hazards, 5(1), 57-63, 1987.
Soloviev, S. L., Solovieva, O. N., Go, C. N., Kim, K. S., and Shchetnikov, N. A.: Tsunamis in the Mediterranean Sea 2000 B.C.2000 A.D., Adv. Nat. Technol. Hazards Res., Kluwer, Dordrecht, 13, 360 p, 2000.

Tinti, S., Maramai, A., and Graziani, L.: A new version of the European tsunami catalogue: updating and revision, Nat. Hazards Earth Syst. Sci., 1, 255-262, 2001, http://www.nat-hazards-earth-syst-sci.net/1/255/2001/.

Tinti, S., Maramai, A., and Graziani, L.: The new catalogue of the Italian tsunamis, Nat. Hazards, 33, 439-465, 2004.

Tintoré, J., Gomis, D., Alonso, S., and Wang, D. P.: A theoretical study of large sea level oscillations in the Western Mediterranean, J. Geophys. Res., 93, 10 797-10 803, 1988.

Titov, V. V., Rabinovich, A. B., Mofjeld, H., Thomson, R. E., and González, F. I.: The global reach of the 26 December 2004 Sumatra tsunami, Science, 309, 2045-2048, 2005.

Vilibić, I.: Numerical study of the Middle Adriatic coastal waters sensitivity to the various air pressure travelling disturbances, Ann. Geophys., 23, 3569-3578, 2005, http://www.ann-geophys.net/23/3569/2005/.

Vilibić, I. and Mihanović, H.: A study of resonant oscillations in the Split harbour (Adriatic Sea), Estuar. Coastal Shelf Sci., 56, 861-867, 2003.

Vilibić, I., Domijan, N., Orlić, M., Leder, N., and Pasarić, M.: Resonant coupling of a traveling air-pressure disturbance with the east Adriatic coastal waters, J. Geophys. Res., 109, C10001, doi:10.1029/2004JC002279, 2004.

Vilibić, I., Domijan, N., and Čupić, S.: Wind versus air pressure seiche triggering in the Middle Adriatic coastal waters, J. Mar. Syst., 57, 189-200, 2005.

Wang, X., Li, K., Yu, Z., and Wu, J.: Statistical characteristics of seiches in Longkou Harbour, J. Phys. Oceanogr., 17, 1963-1966, 1987.

Wilson, B.: Seiches, Adv. Hydrosci., 8, 1-94, 1972. 